\title{
Drought and vegetation change in the central Rocky Mountains and western Great Plains: potential climatic mechanisms associated with megadrought conditions at 4200 cal yr BP
}

\author{
Vachel A. Carter ${ }^{1,2}$, Jacqueline J. Shinker ${ }^{3}$, and Jonathon Preece ${ }^{3}$ \\ ${ }^{1}$ RED Lab, Department of Geography, University of Utah, Salt Lake City, UT 84112, USA \\ ${ }^{2}$ Department of Botany, Charles University, Prague, 12801, Czech Republic \\ ${ }^{3}$ Department of Geography and Roy J. Shlemon Center for Quaternary Studies, \\ University of Wyoming, Laramie, WY 82071, USA
}

Correspondence: Vachel A. Carter (vachel.carter@gmail.com)

Received: 28 August 2017 - Discussion started: 29 September 2017

Revised: 22 July 2018 - Accepted: 24 July 2018 - Published: 15 August 2018

\begin{abstract}
Droughts are a naturally re-occurring phenomena that result in economic and societal losses. Yet, the most historic droughts that occurred in the 1930s and 1950s in the Great Plains and western United States were both shorter in duration and less severe than megadroughts that have plagued the region in the past. Roughly 4200 years ago, a $\sim 150$-year long megadrought occurred in the central Rocky Mountains, as indicated by sedimentary pollen evidence documenting a brief and unique change in vegetation composition from Long Lake, southeastern Wyoming. Neighbouring the central Rocky Mountains, several dune fields reactivated in the western Great Plains around this time period illustrating a severe regional drought. While sedimentary pollen provides evidence of past drought, paleoecological evidence does not provide context for the climate mechanisms that may have caused the drought. Thus, a modern climate analogue technique was applied to the sedimentary pollen and regional dune reactivation evidence identified from the region to provide a conceptual framework for exploring possible mechanisms responsible for the observed ecological changes. The modern climate analogues of 2002/2012 illustrate that warm and dry conditions persisted through the growing season and were associated with anomalously higher-than-normal geopotential heights centred over the Great Plains. In the spring, higher-than-normal heights suppressed moisture transport via the low-level jet from the Gulf of Mexico creating a more southwesterly component of flow. In the summer, higher-than-normal heights persisted over the northern Great Plains resulting in a wind shift with
\end{abstract}

an easterly component of flow, drawing in dry continental air into the study region. In both cases, lower-than-normal moisture in the atmosphere (via 850 mbar specific humidity) inhibited uplift and potential precipitation. Thus, if the present scenario existed during the $4.2 \mathrm{ka}$ drought, the associated climatic responses are consistent with local and regional proxy data suggesting regional drought conditions in the central Rocky Mountains and western Great Plains.

\section{Introduction}

Droughts are a regular climatic feature in the Great Plains and western United States (US). As global temperatures continue to rise as a result of anthropogenically induced climate change (IPCC, 2014), drought vulnerability is predicted to increase in the Great Plains and western US (Garfin et al., 2013). Of the 20th century droughts, the 1930s and 1950s droughts were the most extensive and long lasting (Schubert et al., 2004), which caused both economic and societal losses throughout the regions (Diaz, 1983; Woodhouse and Overpeck, 1998). Yet, when compared to proxy data, modern era droughts were both shorter in duration and less severe than megadroughts that have plagued the region in the past (Woodhouse and Overpeck, 1998; Cook et al., 2010). Megadroughts can be defined as persistent drought events that last decades to centuries and generally have a large spatial extent (Woodhouse and Overpeck, 1998). However, little is known about what causes megadroughts. Droughts and 


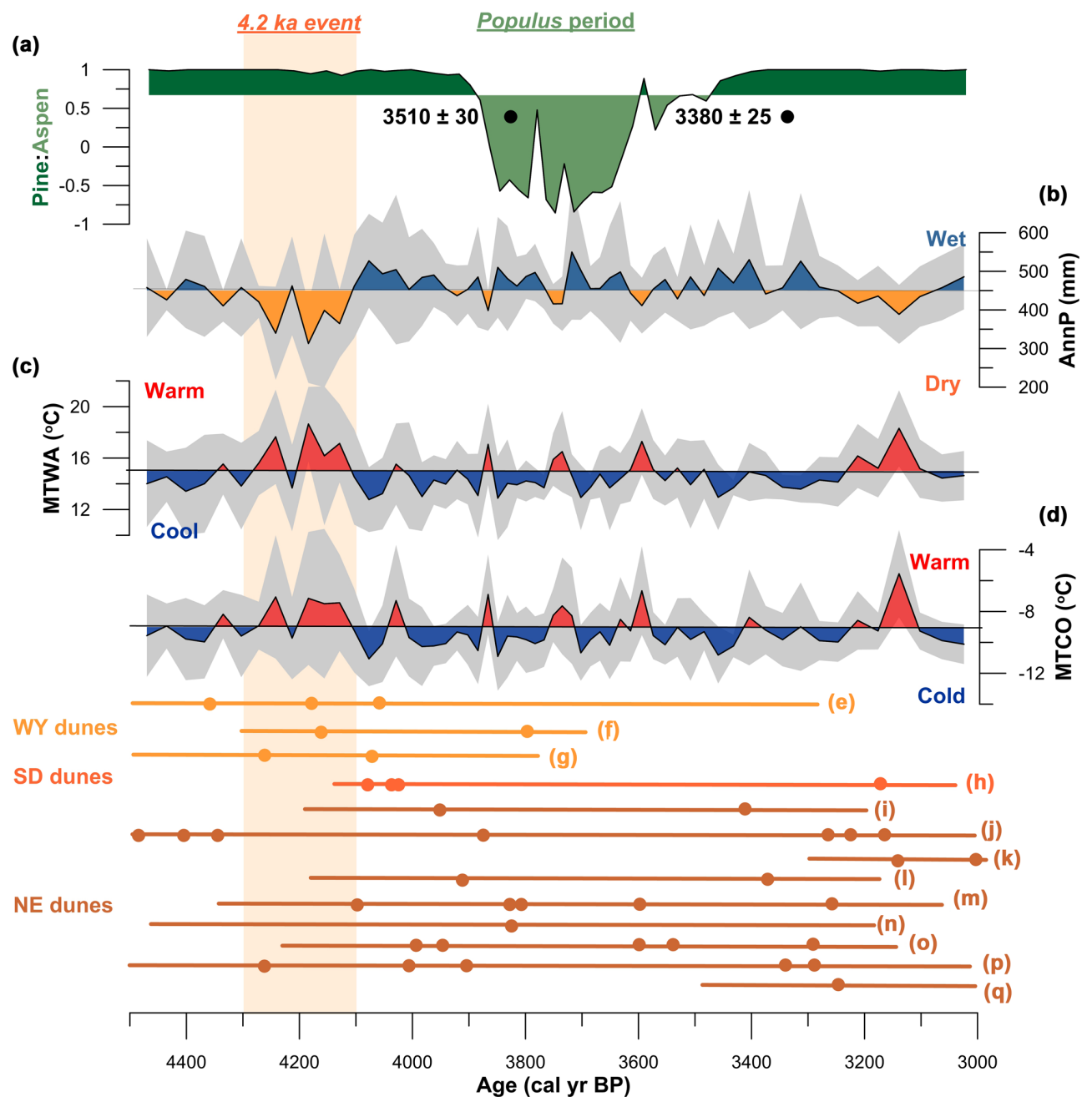

Figure 1. Regional paleo-proxy evidence supporting drought conditions between $\sim 4200$ and $\sim 4000$ cal yr BP. (a) Pine : Aspen pollen ratio showing the Populus period - a change from a lodgepole-pine-dominated forest to a mixed forest of lodgepole pine and quaking aspen - from Long Lake, southeastern Wyoming (Carter et al., 2013). Black circles illustrate radiocarbon dates that were used to temporally constrain the Populus period; (b-d) Reconstructed climate variables from Long Lake, southeastern Wyoming - annual precipitation (AnnP), mean temperature of the warmest month (MTWA); mean temperature of the coldest month (MTCO) (Carter et al., 2017a); (e-q) clusters of radiocarbon and luminescence dates from regional sand dunes - age data error bars reflect those reported by the original authors, typically 1 to $2 \sigma$; (e) Ferris dunes, Wyoming (Stokes and Gaylord, 1993); (f-g) Casper dunes, Wyoming (Halfen et al., 2010); (h) White River Badlands dunes, South Dakota (Rawling et al., 2003); (i) Nebraska Hills dunes, Nebraska (Schmieder et al., 2011); (j) Nebraska Hills dunes (Miao et al., 2007); (k-l) Nebraska Hills dunes (Mason et al., 2004); (m) Nebraska Hills dunes (Goble et al., 2004); (n) Nebraska Hills dunes (Stokes and Swinehart, 1997); (o) Nebraska Hills dunes (Loope et al., 1995); (p) Nebraska Hills dunes (Ahlbrandt et al., 1983); (q) Nebraska Hills dunes (Madole, 1995). Orange shading denotes the 4.2 ka drought. Data were modified from Carter et al. (2013, 2017a), and Halfen and Johnson (2013).

likely megadroughts are climatically complex processes that are typically not attributed to a single cause, but rather to multiple causes (Namias, 1991). Yet, it is postulated that processes responsible for modern droughts, such as sea-surface temperatures (SSTs), land-atmosphere interactions, and internal atmospheric variability (see Cook et al., 2016, and references therein) may have mechanistically contributed to historic megadroughts. Understanding the mechanisms involved with megadroughts is of critical importance due to the poten- tial for similar extreme drought events to occur in the future (Coats et al., 2013).

One such megadrought was identified approximately 4200 cal yr BP via sedimentary proxy data from Long Lake, southeastern Wyoming located in the eastern-most extent of the central Rocky Mountains (CRM; Carter et al., 2013, 2017a). Proxy evidence from Long Lake documents the lagged ecological response of a pine-dominated forest turning to a mixed-forest with pine and quaking aspen (Fig. 1a), 
which the authors coined as the "Populus period" (Carter et al., 2013). This same ecological response was also recorded in the modern record from Long Lake likely in response to the 1930s drought (Carter et al., 2017a). The relationship between drought, increased temperatures, and widespread quaking-aspen mortality has been observed across western North America (Anderegg et al., 2013a, b; Hanna and Kulakowski, 2012; Hogg et al., 2008; Kashian et al., 2007; Rehfeldt et al., 2009; Worrall et al., 2008, 2010, 2013). Carter et al. (2017a) further investigated the role that climate variability and wildfire activity had on the persistence of quaking aspen during the Populus period, and determined that increased temperatures associated with a $\sim 150$-year long megadrought (Fig. 1b-d) likely caused the upslope migration of quaking-aspen stands in the Medicine Bow Mountains of southeastern Wyoming. The timing of the reconstructed drought at Long Lake may be associated with the $4.2 \mathrm{ka}$ climatic event which was a prominent dry period at primarily low-to-mid latitudes that was responsible for cultural collapses globally (deMenocal, 2001; An et al., 2005; Weiss, 2016, 2017a, b). Neighbouring the CRM, drought conditions were also recorded in the Great Plains region approximately 4200 cal yr BP (Booth et al., 2005). Of particular interest to this study are the numerous dune fields that reactivated in the western Great Plains (Fig. 1e-q), indicating geographically extensive droughts around this same time period (Halfen and Johnson, 2013); the Ferris and Casper dune fields of eastern Wyoming (Stokes and Gaylord, 1993; Halfen et al., 2010), the White River Badlands dunes of southwestern South Dakota (Rawling et al., 2003), and the Nebraska Hills dunes of central Nebraska (Schmieder et al., 2011; Miao et al., 2007; Mason et al., 2004; Goble et al., 2004; Stokes and Swinehart, 1997; Loope et al., 1995; Ahlbrandt et al., 1983; Madole, 1995). Yet, Miao et al. (2007) acknowledge that sand dune reactivation could also be a lagged effect of drought. Regardless, prehistoric dune activation follows two assumptions; first, that aeolian transport occurs when particles are abundant and freely available to transport via strong winds; and second, that vegetation cover is reduced leaving sand particles easily exposed to strong winds (Halfen and Johnson, 2013). Thus, it is hypothesized that persistently dry growing-season conditions between $\sim 4200$ and $\sim 4000$ cal yr BP likely led to lagged changes in vegetation composition at Long Lake, as well as reduced dune-stabilizing vegetation across the western Great Plains region.

While sedimentary proxy data such as pollen and charcoal provide a record of changes in past vegetation and disturbances (e.g. fires or drought), they do not provide a record of the climatic mechanisms that initially caused such extreme events. Thus, improving our understanding of the climate processes associated with modern drought will provide better insight into past drought variability and the mechanisms associated with megadroughts evident in paleoecological records. One tool we can use to understand the cli- mate processes associated with past drought seen in proxy data is through the use of the modern climate analogue technique (Mock and Shinker, 2013), which assumes that modern synoptic and dynamic climate processes operated similarly in the past as they do today. The modern climate analogue technique is a conceptual model that uses modern extremes (e.g. drought) as analogues of past events (e.g. vegetation change associated with drought) as a means to understand paleoclimate patterns that may have caused historic paleoecological variability (Diaz and Andrews, 1982; Ely, 1997; Edwards et al., 2001; Shinker, 2014; Mock and Bartlein, 1995; Mock and Brunelle-Daines, 1999; Mock and Shinker, 2013; Shinker et al., 2006; Carter et al., 2017b). The modern climate analogue approach has been previously used to understand past synoptic processes and ecological changes recorded in paleoenvironmental data. For example, Mock and Brunelle-Daines (1999) investigated how summer synoptic climatology and external forcing (i.e. Milankovich cycles) impacted effected moisture in the western US during the mid-Holocene $(\sim 6000$ cal yr BP). Shinker et al. (2006) also examined the mid-Holocene drought, but focused on the mid-continent of North America to provide potential climate processes and mechanisms associated with low lake levels during the prolonged mid-Holocene drought. They found that regional moisture influx and small-scale vertical motions in the atmosphere help explain low lake levels during that time. Similarly, Shinker (2014) investigated climatic controls on water resources in the headwaters of the Upper Arkansas River basin in west-central Colorado and found that localscale variations in moisture availability and the absence of uplift mechanisms were key in explaining hydroclimate variability evidenced in lake-level reconstructions (Shuman et al., 2009). Edwards et al. (2001) used the same technique to understand how specific atmospheric circulation patterns could have caused surface temperature and effective moisture anomalies during the past 12000 years in the interior of Alaska. Finally, Carter et al. (2017b) used modern climate analogues to investigate how atmospheric conditions could have potentially contributed to the unique spatial patterns of wildfire activity over the past 1500 years in the northern and southern Rocky Mountains.

In lieu of climate simulations for the $4.2 \mathrm{ka}$ event, the objective of this paper is to examine modern climate analogues as an alternative approach for understanding circulation patterns and potential heterogeneous surface responses between $\sim 4200$ and $\sim 4000$ cal yr BP in the CRM and western Great Plains region. The purpose of using the modern climate analogue in this study is not to reconstruct circulation patterns that may have prevailed during the $4.2 \mathrm{ka} \mathrm{cli-}$ matic event, rather the purpose is to offer insights into potential synoptic processes that may have facilitated the paleoecological responses evidenced in the both the CRM and Great Plains at that time (Mock and Bartlein, 1995). Climate analogues were selected on the basis that they best represented the environment-to-circulation approach (Barry 


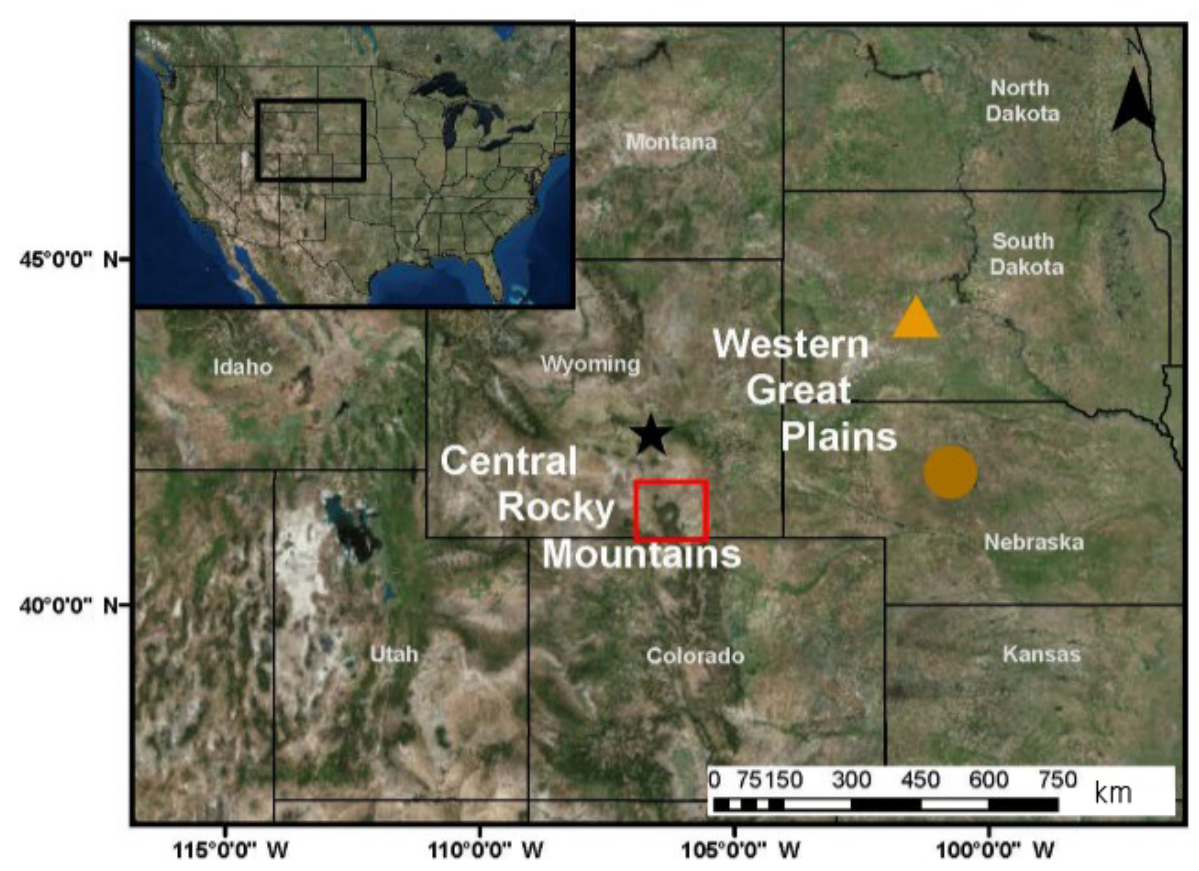

Figure 2. Location map of the study region in the western United States (inset panel; black box). Sedimentary proxy data analysed in this study come from Long Lake, Wyoming (red box) located in southeastern Wyoming within the central Rocky Mountain region on the edge of the western Great Plains. Long Lake experienced a unique change in vegetation composition $\sim 4000$ cal yr BP in response to persistent drought conditions $\sim 4200 \mathrm{cal}$ yr BP. Regionally, several dune fields reactivated in response to regional droughts $\sim 4000$ cal yr BP; the black star depicts the region where the Ferris dunes (Stokes and Gaylord, 1993) and Casper dunes (Halfen et al., 2010) are located. The orange triangle depicts the White River Badlands dunes (Rawling et al., 2003) of South Dakota. Lastly, the brown circle indicates the Nebraska Hills dune field (Schmieder et al., 2011; Miao et al., 2007; Mason et al., 2004; Goble et al., 2004; Stokes and Swinehart, 1997; Loope et al., 1995; Ahlbrandt et al., 1983; Madole, 1995).

and Carleton, 2001; Mock and Shinker, 2013; Shinker, 2014; Yarnal, 1993; Yarnal et al., 2001), i.e. anomalously dry conditions similar to those experienced during the $4.2 \mathrm{ka}$ event identified in the sedimentary proxy data at Long Lake, southeastern Wyoming (Carter et al., 2017a), as well as by clusters of radiocarbon and luminescence dates that indicate drought conditions in the western Great Plains (Stokes and Gaylord, 1993; Halfen et al., 2010; Rawling et al., 2003; Schmieder et al., 2011; Mason et al., 2004; Goble et al., 2004; Stokes and Swinehart, 1997; Loope et al., 1995; Ahlbrandt et al., 1983; Madole, 1995). The present-day climatology of southeastern Wyoming (Mock, 1996; Shinker, 2010) indicates that the region exhibits similar precipitation influences as the western Great Plains (e.g. springtime precipitation maximum). Thus, we hypothesize that due to Long Lake's geographical position, i.e. the eastern-most extent in the CRM, our study site is sensitive to broad-scale climatic processes influencing the western Great Plains.

\section{Study area}

Long Lake $\left(41^{\circ} 30.099^{\prime} \mathrm{N}, 106^{\circ} 22.087^{\prime} \mathrm{W} ; 2700 \mathrm{~m}\right.$ a.s.1.) is located within the Upper Platte River watershed in the
Medicine Bow Mountains of southeastern Wyoming (Fig. 2). The study site experiences a snow-dominated winter precipitation with a May precipitation maximum (Mock, 1996; Shinker, 2010), albeit that the May precipitation maximum only accounts for $12-15 \%$ of the total annual precipitation (Shinker, 2010). Interpolated modern January and July precipitation and temperatures from the nearest weather station suggest an average of 330 and $690 \mathrm{~mm}$, and -9.7 and $11^{\circ} \mathrm{C}$, respectively (NRCS, unpublished data). Using the modern pollen analogue technique (Overpeck et al., 1985), Carter et al. (2017a) reconstructed the mean temperature of the coldest month (MTCO; i.e. January), mean temperature of the warmest month (MTWA; i.e. July), and annual precipitation, which averaged $-9,15^{\circ} \mathrm{C}$, and $\sim 443 \pm 39 \mathrm{~mm}$ over the past $\sim 2000$ years, respectively. During the drought between 4300 and $4100 \mathrm{cal} \mathrm{yr} \mathrm{BP,} \mathrm{MTCO,} \mathrm{MTWA,} \mathrm{and} \mathrm{annual} \mathrm{pre-}$ cipitation averaged $-8,16^{\circ} \mathrm{C}$, and $394 \pm 58 \mathrm{~mm}$ (Fig. $1 \mathrm{~b}-\mathrm{d}$; Carter et al., 2017a). Both the modern and reconstructed climate from the area highlights that the Medicine Bow Mountains has a high degree of precipitation variability likely related to natural fluctuations in the strength and position of the jet stream. Currently, the study region does not experience 
statistically significant seasonal precipitation patterns associated with ENSO phases (Wise, 2010; Heyer et al., 2017).

Modern vegetation at Long Lake is comprised mostly of lodgepole pine (Pinus contorta), with Engelmann spruce (Picea engelmanni), and subalpine fir (Abies lasiocarpa) on more mesic soils. Lodgepole pine has been the dominant canopy cover type for the past $\sim 8000$ years (Carter et al., 2013). Currently, the modern geographical location of the aspen ecotone is roughly $200 \mathrm{~m}$ a.s.l. downslope from Long Lake, yet the modern upper limit of aspen on north-facing slopes in the Medicine Bow Mountains is similar to the elevation at Long Lake (Carter et al., 2017a).

Carter et al. (2013, 2017a) describe the sedimentary collection that took place at Long Lake in 2007, while Carter et al. (2017a) describe age-depth relations, charcoal and pollen analysis, and the modern pollen analogue technique which was used to reconstruct local temperature and precipitation values. Additionally, Carter et al. (2017a) updated the agedepth relations from Carter et al. (2013) with the addition of an accelerator mass spectrometry radiocarbon date that was used to temporally constrain the upper and lower ages of the "Populus" period (Fig. 1a; also see Carter et al., 2017a), as well as provide an upper age constraint on the drought at 4200 cal yr BP.

\section{Methods}

\section{Modern climate analogues and calculation of composite-anomaly values}

To investigate potential climate mechanisms that may be associated with the ecological changes at Long Lake, Wyoming, a time series of modern precipitation anomalies was calculated from Wyoming Climate Division 10, the Upper Platte River basin, using data from the National Climate Data Centre (NCDC; Fig. 3). Time series of modern precipitation anomalies were also calculated from Wyoming Climate Division 8, South Dakota Climate Division 5, and $\mathrm{Ne}$ braska Climate Division 2 (Fig. 3), as these climate divisions encompass the Ferris and Casper dune fields, the White River Badlands dune fields, and the Nebraska Hills sand dunes, respectively. For all four time series, annual average precipitation values from 1979 to 2014, the common period for the North American Regional Reanalysis (NARR) dataset, were compared to the long-term mean (1981-2010). From the time series, potential analogues were selected based on a few criteria; first, anomalously dry conditions must have occurred during the same year(s) in all four climate divisions; and second, case years were greater than -1 standard deviations (one SD equals $58.89 \mathrm{~mm}$ at Wyoming 10; $59.73 \mathrm{~mm}$ at Wyoming 8; $91.61 \mathrm{~mm}$ at South Dakota 5; and $101.43 \mathrm{~mm}$ at Nebraska 2) below the long-term average, i.e. within the 10 th percentile of dry years. These case years thus represent the driest conditions across all four climate divisions, and are clearly representative of highly anomalously widespread dry conditions, as likely occurred during the $4.2 \mathrm{ka}$ climatic event at Long Lake, the Ferris and Casper dune fields, White River Badlands dune fields, and Nebraska Hills sand dunes. Once the case years were identified (2002 and 2012), annual precipitation of each case year was compared to the 19812010 climate normal at each grid point in our study region using a two-tailed Student's $t$ test with an alpha of 0.05 . The degrees of freedom (30) were calculated as $n 1+n 2-2$, where $n 1=30$ and corresponds to the number of years in the climate normal, and $n 2=2$, for the number of case years. Precedence for using a $t$ test to calculate statistical significance of anomalies in climatological analyses is well established in the existing literature (Cayan, 1996; Shabbar and Khandekar, 1996; Taschetto and England, 2009). The results are presented in a map depicting the spatial distribution of significant $p$ values across our study region (Fig. 4).

A variety of surface and atmospheric climate variables from the NARR dataset (Mesinger et al., 2006) were analysed and mapped to assess potential linkages among synoptic processes and ecological changes between $\sim 4200$ and $\sim 4000$ calyr BP. The NARR dataset is advantageous for two reasons: (1) it provides a variety of climate variables that represent atmospheric synoptic processes (e.g. atmospheric pressure, wind direction and speed, moisture availability, and vertical motions), as well as surface conditions (e.g. precipitation rate and temperature); and (2) the spatial resolution ( $32 \mathrm{~km}$ grids) of the NARR dataset is at a finer scale than large-scale GCMs making the NARR dataset useful for assessing hydroclimate impacts at high spatial resolution (Heyer et al., 2017). Additionally, the $32 \mathrm{~km}$ resolution is valuable for capturing the topographic and climate diversity of the geographic study region. The seasonal values (e.g. winter = December, January, February (DJF); spring = March, April, May (MAM); summer = June, July, August (JJA); and fall=September, October, November (SON)) of the selected modern analogue case years were averaged together (composited) and compared to the longterm mean (1981-2010) to create composite-anomaly values for each season. Surface variables were mapped at a regional level to illustrate the spatial heterogeneity of such processes. Atmospheric variables were mapped at a continental scale to illustrate the large spatial scales in which such variables operate. Composite-anomaly values were calculated using the NARR Monthly/Seasonal Climate Composites plotting and analysis page (https://www.esrl.noaa.gov/psd/ cgi-bin/data/narr/plotmonth.pl, last access: 26 June 2018). The resultant netCDF (Network Common Data Form) files were plotted graphically using the NASA/GISS software, Panoply, a netCDF data viewer (https://www.giss.nasa.gov/ tools/panoply/, last access: 26 June 2018). The resulting maps are plotted using the NARR $32 \mathrm{~km}$ gridded format and have not been interpolated in order to maintain the native spatial representation of the data. 

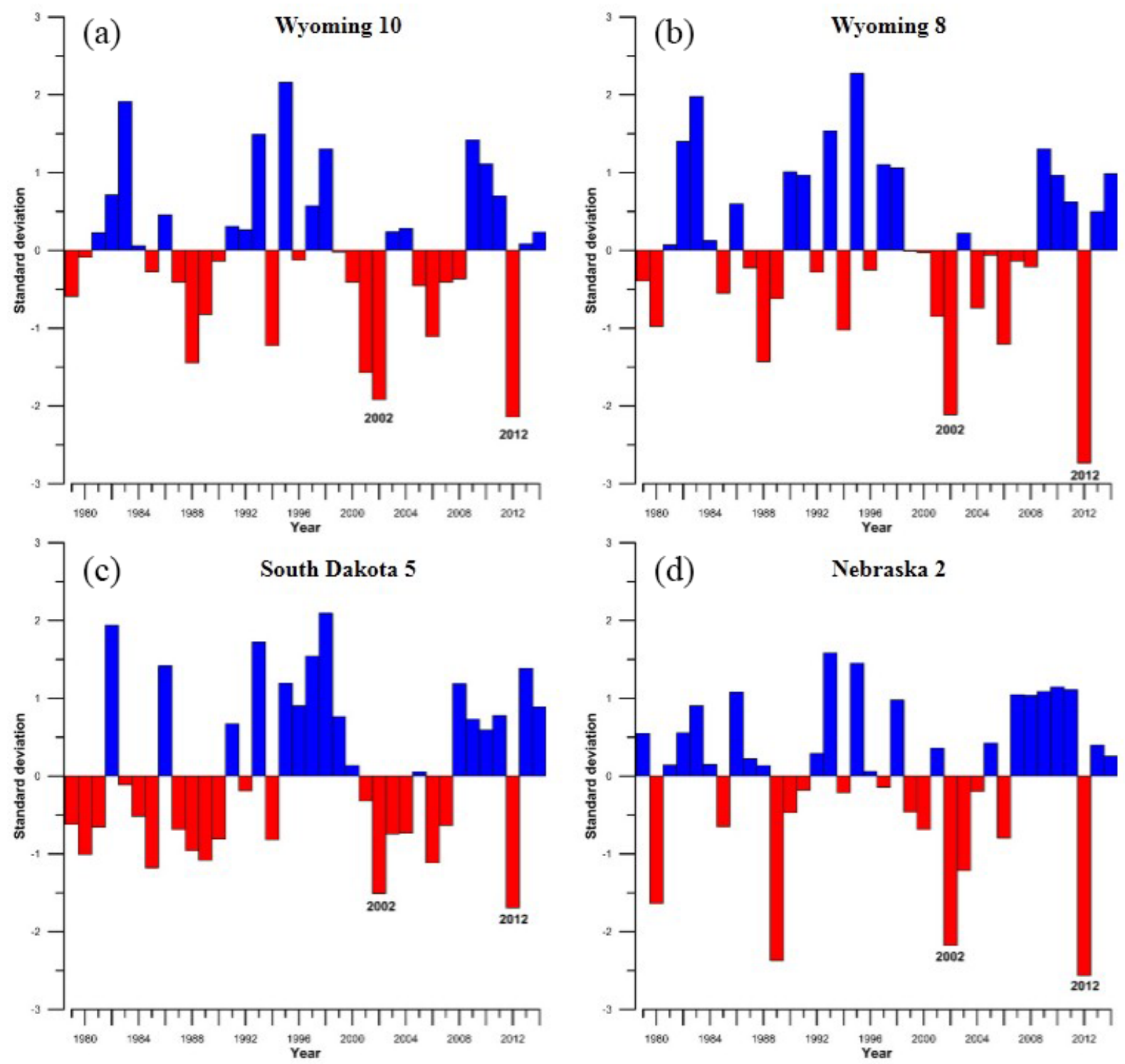

Figure 3. Time series of precipitation anomalies from Wyoming Climate Divisions 10 (a) and 8 (b), South Dakota Climate Division 5 (c), and Nebraska Climate Division 2 (d). Annual precipitation anomalies for 1979-2014 were compared to the long-term average (1981-2010) from each climate division. Case years that were greater than -1 standard deviations below the long-term average, or in the 10th percentile, were chosen as modern analogues to investigate dry conditions during the 4.2 ka megadrought in the central Rocky Mountains (Carter et al., 2017a), and western Great Plains (Stokes and Gaylord, 1993; Halfen et al., 2010; Rawling et al., 2003; Schmieder et al., 2011; Miao et al., 2007; Mason et al., 2004; Goble et al., 2004; Stokes and Swinehart, 1997; Loope et al., 1995; Ahlbrandt et al., 1983; Madole, 1995). Climate division data were collected from https://www.esrl.noaa.gov/psd/data/timeseries/ (last access: 26 June 2018).

\section{Results}

\subsection{Modern climate analogues of extreme dry conditions in the CRM and western Great Plains}

\subsubsection{Surface modern climate analogues}

The composite-anomaly maps for precipitation rate provide the spatial representation of the information shown in the time series of annual precipitation seen in Fig. 3. Winter
(DJF) precipitation rate composite-anomaly values are above normal near Long Lake, as well as near both the Ferris and Casper dune fields, but slightly below normal near the White River Badlands and Nebraska Hills sand dunes (Fig. 5a). Spring (MAM) precipitation rate composite-anomaly values indicate a shift towards significantly drier-than-normal conditions across the entire study region (Fig. 5b), which persisted through the summer (JJA, Fig. 5c) and into the fall (SON, Fig. 5d). 


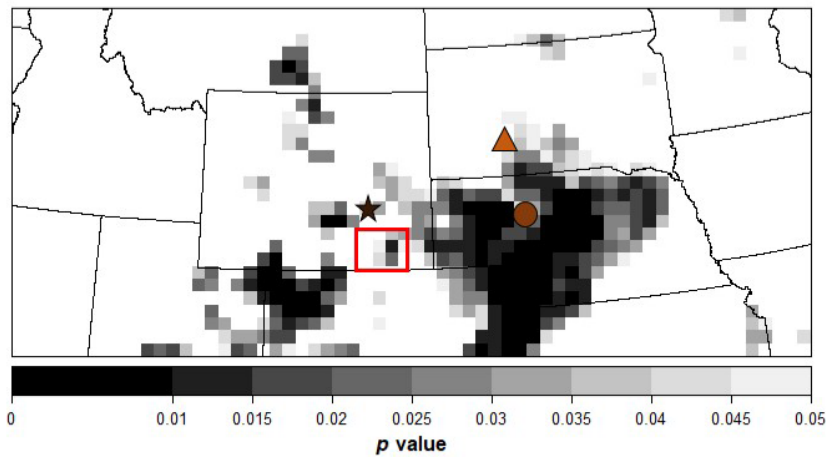

Figure 4. Map showing the spatial distribution of significant $p$ values $(p<0.05)$ during the two case years (2002 and 2012) across the central Rocky Mountains and western Great Plains, USA. $P$ values were evaluated using a two-tailed Student's $t$ test with an alpha of 0.05. Sedimentary proxy data from Long Lake, Wyoming (red box), as well as clusters of radiocarbon and luminescence dates from the Ferris and Casper dune fields (black star), the White River Badlands dunes (orange triangle), and the Nebraska Hills sand dunes (brown circle), all recorded severe drought conditions between $\sim 4200$ and $\sim 4000$ cal yr BP (Carter et al., 2017a; Stokes and Gaylord, 1993; Halfen et al., 2010; Rawling et al., 2003; Schmieder et al., 2011; Miao et al., 2007; Mason et al., 2004; 2011; Goble et al., 2004; Stokes and Swinehart, 1997; Loope et al., 1995; Ahlbrandt et al., 1983; Madole, 1995).

Composite-anomaly maps for winter (DFJ) temperature indicate cooler-than-normal conditions near Long Lake, as well as near both the Ferris and Casper dune fields, but warmer-than-normal conditions near the White River Badlands and Nebraska Hills sand dunes (Fig. 6a). Positive temperature anomalies increased during the spring (Fig. 6b), and became increasingly warmer-than-normal during the summer across the entire study region (JJA; Fig. 6c). Temperatures were slightly warmer-than-normal across the entire study region during the fall (SON, Fig. 6d).

\subsubsection{Atmospheric modern climate analogues}

Geopotential height at the 500 mbar level provides information about atmospheric pressure in the mid-troposphere. Thus, it was used in this study to examine the influence of lower-than-normal atmospheric pressure (associated with enhanced troughs), and higher-than-normal atmospheric pressure (associated with enhanced ridges) on surface conditions. Winter (DJF) 500 mbar geopotential height composite-anomaly values show slightly higher-thannormal heights centred off both US coasts (Fig. 7a). Spring (MAM) composite-anomaly values indicate higher-thannormal heights centred over the central Great Plains and southeastern US region (Fig. 7b), which shifted north over the American Midwest and northern Great Plains region during the summer (JJA, Fig. 7c). Fall (SON) compositeanomaly values show higher-than-normal heights off the coast of British Columbia, and lower-than-normal pressure centred over interior Canada (Fig. 7d).

The 500 mbar vector wind composite-anomaly maps provide information about wind direction and anomalous component of flow (Fig. 8), associated with the 500 mbar geopotential height composite-anomaly values. For winter (DJF), there is no anomalous component of flow into the study region (Fig. 8a) as the study region resides in between two anomalous high-pressure centres centred over the eastern and western US coasts (Fig. 7a). During the spring (MAM), the anomalous component of flow is from the southwest (Fig. 8b) associated with the clockwise flow of air around the anomalous ridge centred over the central Great Plains and southeastern US region (Fig. 7b). During the summer (JJA), the anomalous component of flow is from the east, southeast (Fig. 8c) associated with the clockwise flow of air around the anomalous ridge over the Midwest and northern Great Plains region seen in Fig. 7c. For fall (SON), the anomalous component of flow is northerly into the study region (Fig. 8d).

While the $500 \mathrm{mbar}$ geopotential height and $500 \mathrm{mbar}$ vector wind composite-anomaly maps provide a continental perspective of broad-scale anomalous ridges and troughs and subsequent advection of wind, 500 mbar omega (vertical velocity) offers a more local-scale perspective on secondary sinking and rising motions that occur within ridges and troughs, respectively. Specifically, positive $500 \mathrm{mbar}$ omega composite-anomaly values show anomalous sinking motions indicating suppression of precipitation, and negative 500 mbar omega composite-anomaly values indicate anomalous rising motions that enhance precipitation (Fig. 9). Winter (DJF) 500 mbar omega composite-anomaly values indicate slight rising motions over both Long Lake and the Ferris and Casper dune fields, and slight sinking motions over the White River Badlands and Nebraska Hills sand dunes (Fig. 9a). However, rising motions become anomalously positive over Long Lake, and the Ferris and Casper dune fields during the spring (MAM) and fall (SON, Fig. 9b and d). Sinking motions prevail over the White River Badlands and Nebraska Hills sand dunes during the growing season, i.e. spring through fall. Summer (JJA) composite-anomaly values show a mixture of weak rising and sinking motions over Long Lake and the Ferris and Casper dune fields (Fig. 9c).

Lastly, the 850 mbar specific humidity composite-anomaly values provide context on the spatial extent of atmospheric moisture available for uplift by omega during each season (Fig. 10). Seasonal 850 mbar specific humidity compositeanomaly values are below normal across the entire study region throughout the year (Fig. 10a-d). 
(a) Winter - DJF

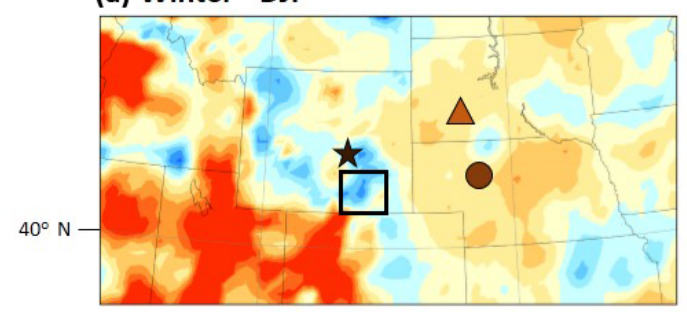

(c) Summer - JJA

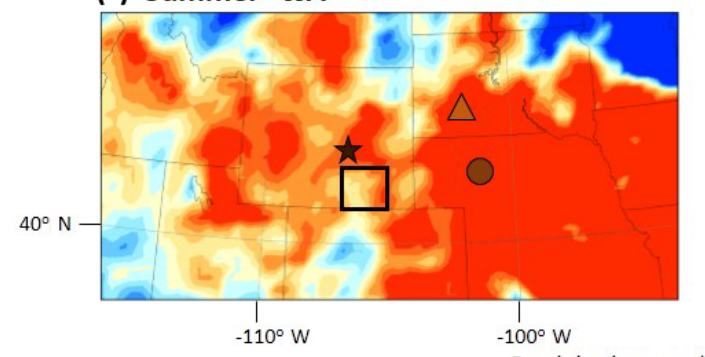

(b) Spring - MAM

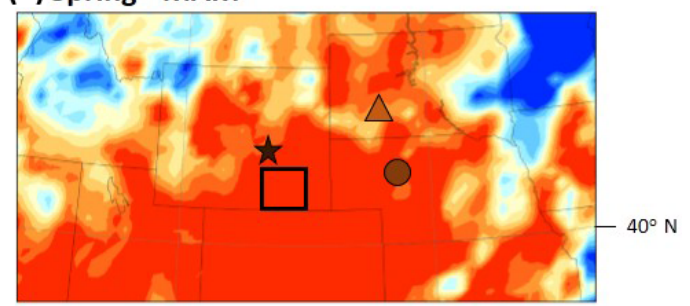

(d) Fall - SON

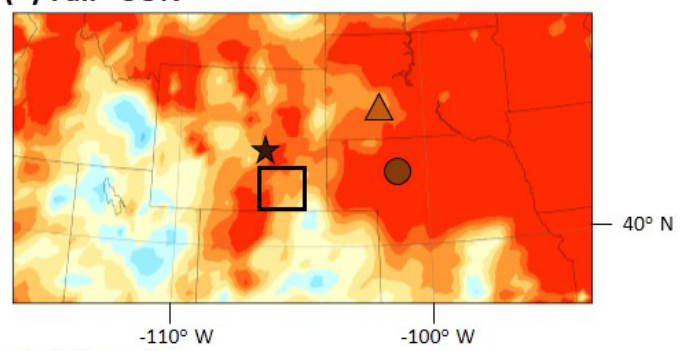

Precipitation rate $\left(10^{-6} \mathrm{~kg} \mathrm{~m}^{-2} \mathrm{~s}^{-1}\right)$

Figure 5. Composite-anomaly maps for precipitation rate at the surface during (a) winter (DJF); (b) spring (MAM); (c) summer (JJA); and (d) fall (SON). Positive values (cool colours) for precipitation rate indicate wetter-than-normal conditions. Negative values (warm colours) indicate drier-than-normal conditions. The black box denotes the study site, Long Lake in the Medicine Bow Mountains of southeastern Wyoming. The black star denotes the Ferris and Casper dune fields; the orange triangle denotes the White River Badlands dunes; and the brown circle denotes the Nebraska Hills sand dunes. Light grey lines depict lines of latitude and longitude.

\section{Discussion}

\subsection{The 4.2 ka event and associated regional climate variability}

Multi-decadal to centennial-scale droughts were common phenomena in the Great Plains and western US during the late Holocene (Woodhouse and Overpeck, 1998; Cook et al., 2004, 2016; Schmieder et al., 2011), and were likely common phenomena throughout the Holocene. As previously noted, several ecological changes were recorded throughout the CRM and western Great Plains region in response to a severe and long-lasting drought between $\sim 4200$ and $\sim 4000$ cal yr BP (Carter et al., 2017a; Stokes and Gaylord, 1993; Halfen et al., 2010; Rawling et al., 2003; Schmieder et al., 2011; Mason et al., 2004; Goble et al., 2004; Stokes and Swinehart, 1997; Loope et al., 1995; Ahlbrandt et al., 1983; Madole, 1995). These regional ecological responses temporally coincide with drought conditions throughout the Great Plains region (see Booth et al., 2005). Other proxy evidence that supports regional dry conditions around this time are the high concentrations of sand influx between 4200 and 3800 cal yr BP in the Sand Hills of Nebraska (Schmieder, 2009), and lower reconstructed lake levels between $\sim 5000$ and $\sim 3400$ cal yr BP from several lakes in the CRM near Long Lake (Shuman et al., 2014, 2015). Additionally, Shuman and Marsicek (2016) synthesized paleoclimate data from the mid-latitudes of North America (i.e. northern Great Plains), which also support extensive drought conditions between 4700 and 4000 cal yr BP. However, the $4.2 \mathrm{ka}$ event itself was not a predominant feature in their synthesis. Widespread and severe drought conditions were also recorded across western North America between 4700 and 4000 cal yr BP based on pollen, charcoal, diatom, grain-size analysis, testate amoebae assemblages, and speleothem stable isotopes, (Dean, 1997; Bernal et al., 2011; Schmieder et al., 2011; Lundeen et al., 2013; Morris et al., 2013; Wanner et al., 2015; Carter, 2016).

Conversely, cool and wet conditions have also been proposed throughout North America between 5500 and 3800 cal yr BP based on stable isotopes, pollen, tree-ring data, as well as by advances in glaciers (Menounos et al., 2008; Grimm et al., 2011; Maurer et al., 2012; Anderson et al., 2016; Steinman et al., 2016). Namely, Grimm et al. (2011) did not record extensive drought conditions at $4200 \mathrm{cal}$ yr BP in the northern Great Plains. Rather, the authors suggest a regime shift towards wet conditions around 4400 cal yr BP, which counters the finding presented by Booth et al. (2005). Similarly, in the southern Rocky Mountains (SRM), negative excursions in $\delta^{18} \mathrm{O}$ values from $\mathrm{Bi}$ son Lake, Colorado $\sim 4200$ cal yr BP, coupled with increases in spruce (Picea) pollen, are interpreted as being indicative of colder-than-previous temperatures and increased snowfall (Anderson, 2012; Anderson et al., 2015). Lastly, treeline abruptly declined $\sim 4200$ cal yr BP in the Great Basin region further suggesting cool conditions (Salzer et al., 2014). 
(a) Winter - DJF

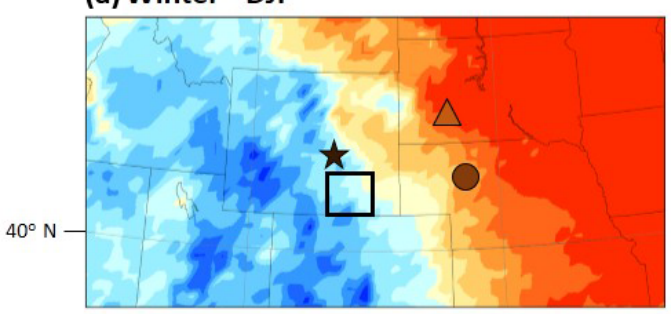

(c) Summer - JJA

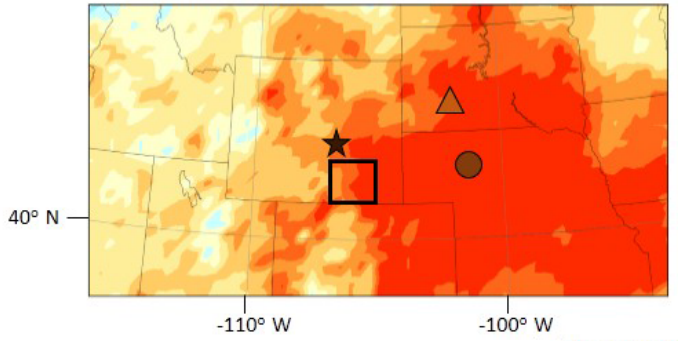

(b) Spring - MAM

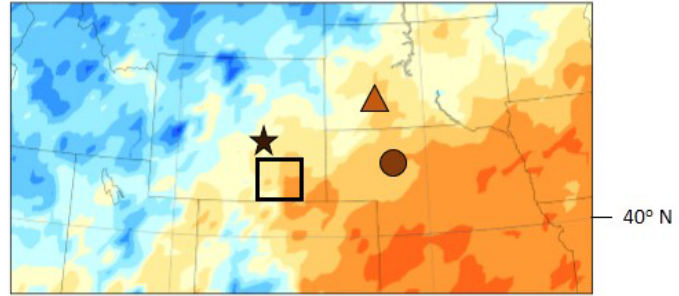

(d) Fall - SON
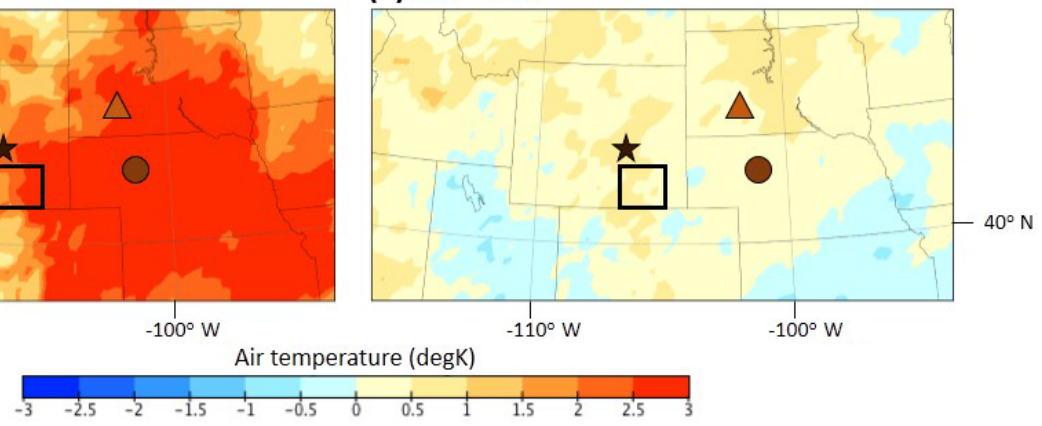

Figure 6. Composite-anomaly maps for air temperature at the surface during (a) winter(DJF); (b) spring (MAM); (c) summer (JJA); (d) and fall (SON). Positive values (warm colours) for air temperature indicate warmer-than-normal conditions. Negative values (cool colours) indicate cooler-than-normal conditions. The black box denotes the study site, Long Lake in the Medicine Bow Mountains of southeastern Wyoming. The black star denotes the Ferris and Casper dune fields; the orange triangle denotes the White River Badlands dunes; and the brown circle denotes the Nebraska Hills sand dunes. Light grey lines depict lines of latitude and longitude.

The ecological variability in proxy data across the western US and Great Plains at this time can be explained by several factors: (1) it could be a function of either site or proxy sensitivity, response time, or temporal resolution; (2) variable ecological responses may be due to surface climate responses to large-scale changes in the polar jet stream or even local-scale variability associated with topographic diversity (Mock, 1996; Shinker, 2010); (3) changes in composite anomalies for point locations can reveal different synoptic conditions (Mock and Anderson, 1997), thus it is to be expected that regions near the study region (i.e. the SRM and northern Great Plains) have different climatological responses; and (4) the 4.2 ka event was imbedded within a period of broad-scale climate reorganization which experienced several important climatic events. The most important climatic events to occur prior to the $4.2 \mathrm{ka}$ event were the onset and intensification of the El Niño Southern Oscillation (ENSO) between 5000 and 4000 cal yr BP (Shulmeister and Lees, 1995; Barron and Anderson, 2010), and the documented switch from a more negative Pacific North-American (PNA) phase (i.e. more enhanced zonal circulation) to a more positive PNA phase (i.e. more enhanced meridional circulation) between 4200 and 4000 cal yr BP (Fisher et al., 2008; Anderson et al., 2016; Liu et al., 2014). Both ENSO and the PNA are primary controls of modern winter climate variability, primarily in the western US (Müller and Roeckner, 2006; Notaro et al., 2006; Allen et al., 2014), although impacts of ENSO in our study region of southeastern Wyoming are minimal (see Heyer et al., 2017 and Wise, 2010). Positive PNA patterns are typically associated with positive winter temperature and negative precipitation anomalies over the Pacific Northwest (Wallace and Gutzler, 1981; Leathers et al., 1991; Allen et al., 2014). Together, these two modes of variability can influence the position of the jet stream which subsequently influences both modern, and likely past, regional temperature and precipitation in certain parts of western North America. Additionally, a weakening of the North American Monsoon (NAM) system is proposed to have occurred between 5000 and $4000 \mathrm{cal}$ yr BP (Metcalfe et al., 2015). The NAM is another source of seasonal precipitation variability in the west, albeit largely in the southwestern portion of North America (Adams and Comrie, 1997; Mock, 1996; Shinker, 2010). While our study region occasionally benefits from advection of moisture recycled from the southwest (Dominguez et al., 2009), the overall atmospheric circulation controls within the CRM is dominated by westerly winds via the polar jet stream, even in the summer (Mock, 1996; Shinker, 2010), versus the shift in circulation-driven winds in the southwest associated with the NAM (Adams and Comrie, 1997).

\subsection{Regional climate variability at 4200 cal yr BP based on modern climate analogues of drought}

Analysing proxy responses is crucial for identifying potential analogues (Fischer et al., 2018). By identifying ex- 


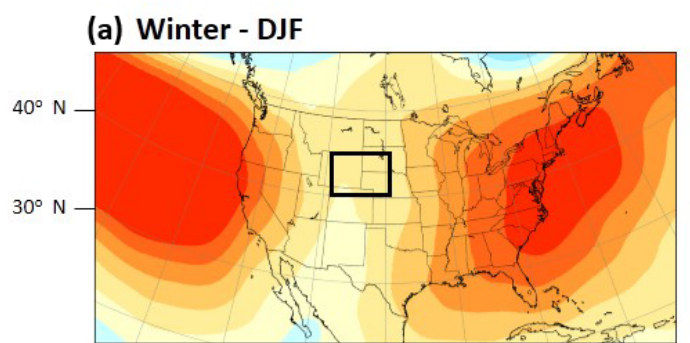

(b) Spring - MAM

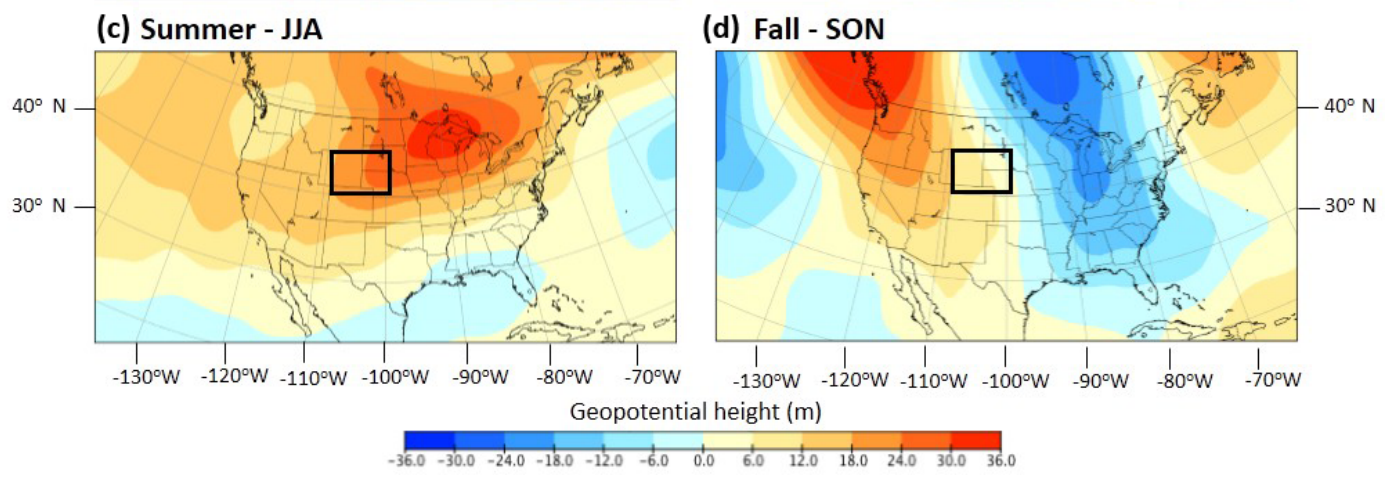

Figure 7. Composite-anomaly maps for 500 mbar geopotential height during (a) winter (DJF); (b) spring (MAM); (c) summer (JJA); and (d) fall (SON). Positive values (warm colours) for 500 mbar geopotential heights indicate a stronger-than-normal ridge. Negative values (cool colours) indicate a strong-than-normal trough. The black box denotes the study region.

treme dry years from modern precipitation data, the modern climate analogue technique is used here to provide a potential scenario of the $4.2 \mathrm{ka}$ drought that occurred in the CRM and western Great Plains. Identified dry case years for our study region illustrate slightly cooler-than-normal and slightly wetter-than-normal winter conditions in Wyoming, yet warmer-than-normal and drier-than-normal conditions across South Dakota and Nebraska (Figs. 5 and 6). Great Plains winter precipitation, specifically January precipitation, is typically dry due to predominant northwesterly flow across the region (Mock, 1996). The slightly wetter than normal conditions in Wyoming cannot be explained by phases of ENSO as the study region is currently positioned within the ENSO dipole transition zone between 40 and $42^{\circ} \mathrm{N}$ (Dettinger et al., 1998; Wise, 2010), where consistently low correlation values between Pacific SST anomalies and cool season precipitation occur (Dettinger et al., 1998; Wise, 2010; Heyer et al., 2017). Thus, winter conditions in southeastern Wyoming and the western Great Plains are currently not impacted by phases of ENSO (Heyer et al., 2017, Wise 2010), and likely haven't been impacted by phases of ENSO throughout the Holocene (Wise, 2016; Carter et al., 2013; Mensing et al., 2013). Therefore, while Barron and Anderson (2010) concluded an enhanced ENSO pattern ca. 4.0 ka BP may have been associated with an increase in winter precipitation in the SRM (Anderson et al., 2012), it is likely that the enhanced ENSO pattern contributed to an increase in variability of the polar jet stream (Heyer et al., 2017). This may have affected proxy-data that is more sen- sitive to winter-time precipitation (e.g. stable isotopes), and thus may have created the spatial inconsistencies of winter precipitation anomalies in the region in the past, i.e. cool and wet conditions identified in the SRM (Anderson et al., 2015) and Pacific Northwest (Steinman et al., 2016).

Winter precipitation is beneficial for vegetation during the growing season in the form of soil recharge via snowpack accumulation, yet peak precipitation maximum in the study region occurs during the late spring, i.e. May (Mock, 1996). Thus, changes in late-spring to early-summer conditions are more likely to impact vegetation and soil recharge across the CRM and western Great Plains. Typically, southerly winds known as the Great Plains low-level jet (Schmeisser et al., 2010) are responsible for bringing in moist air from the Gulf of Mexico to the Great Plains region during late spring to early summer (Sridhar et al., 2006). These southerly winds are associated with the anticyclonic flow around the Bermuda High off the coast of eastern North America. However, if the Great Plains low-level jet is closed off from its moisture source, the Gulf of Mexico, the Great Plains region will essentially be dry during the summer months. Schmeisser et al. (2010) suggest that in order for drought to develop and persist in the Great Plains region during the summer months, the Bermuda High must be reduced or positioned either more easterly or southerly which would create a more southwesterly component of flow. Chang and Smith (2001) suggest several other factors are involved with drought formation in the Great Plains region. First is the prominent anticyclonic feature positioned over the central portion of North Amer- 


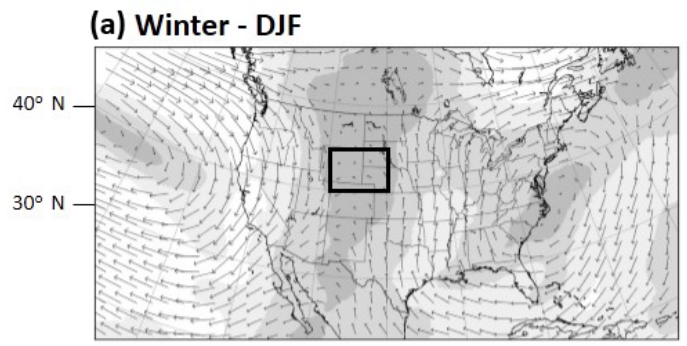

(b) Spring - MAM
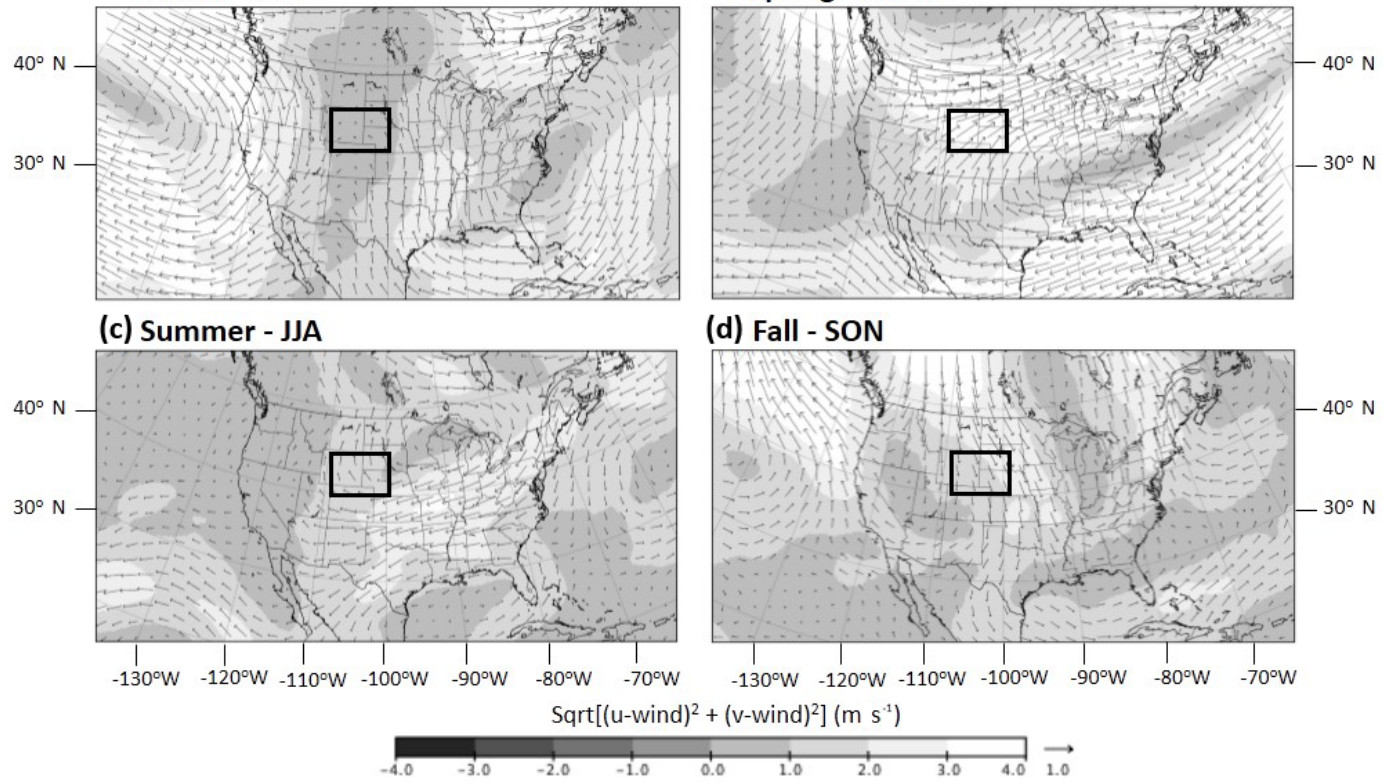

Figure 8. Seasonal composite-anomaly maps for 500 mbar vector winds during (a) winter (DJF); (b) spring (MAM); (c) summer (JJA); and (d) fall (SON). The black box denotes the study region.

ica; second, the mid-tropospheric westerly winds weaken and become easterly winds in association with the anticyclonic high pressure positioned over the Great Plains; and third, the Bermuda high pressure has a westward displacement rather than a reduced or more easterly or southerly position, as suggested by Schmeisser et al. (2010). This westward displacement of the Bermuda high pressure causes the enhancement of a low-level warm flow into the central Great Plains region causing the region to experience negative specific humidity anomalies. Drought conditions proposed by Schmeisser et al. (2010) were experienced during the spring of 2002/2012. Specifically, modern climate analogues clearly demonstrate that the low-level jet was closed off during the spring as a result of an anomalous ridge of high pressure over the southern US and central Great Plains region (Fig. 7b), which resulted in a southwesterly component of flow into the CRM and western Great Plains region (Fig. 8b). This climatic situation likely inhibited growing-season moisture from the Gulf of Mexico via the low-level jet, which is especially important for dune-stabilizing grasses and vegetation in the central Great Plains (Schmieder et al., 2011). In addition, the drought conditions proposed by Chang and Smith (2001) were also experienced during the summer of 2002/2012. Modern climate analogues demonstrate an anticyclonic feature over the north-central Great Plains (Fig. 7c), which resulted in an easterly to southeasterly component of flow into the study region (Fig. 8c). In both scenarios, we can speculate that the Bermuda High was strongly reduced and/or positioned in a way that allowed for the development and persistence of anomalous high-pressure ridges over the cen- tral region of the US throughout the growing season. While there were rising motions present in the Great Plains region throughout the growing season (Fig. 9), lower-than-normal moisture in the atmosphere (via 850 mbar specific humidity) inhibited uplift and potential precipitation (Fig. 10), thus further supporting dry conditions in the study region.

Modern climate analogues clearly demonstrate how drought conditions prevailed during the 2002/2012 growing season, as suggested by Schmeisser et al. (2010) and Chang and Smith (2001), thus offering a potential analogue for drought conditions $\sim 4200$ cal yr BP. Therefore, based on the geographical proximity of our study region to the western Great Plains region, our hypothesis that severe and persistent droughts have the ability to affect the eastern most parts of the CRM is supported by the results of the modern climate analogue technique. Thus, these results offer a potential scenario to mechanistically explain the drought conditions documented at Long Lake $\sim 4200 \mathrm{cal} \mathrm{yr} \mathrm{BP}$, and subsequent lagged ecological changes at Long Lake (Carter et al., 2013, 2017a), and at the Ferris and Casper dune fields of eastern Wyoming (Stokes and Gaylord, 1993; Halfen et al., 2010), the White River Badlands dunes of southwestern South Dakota (Rawling et al., 2003), and the Nebraska Hills dunes of central Nebraska (Schmieder et al., 2011; Miao et al., 2007; Mason et al., 2004; Goble et al., 2004; Stokes and Swinehart, 1997; Loope et al., 1995; Ahlbrandt et al., 1983; Madole, 1995) 4000 cal yr BP. 


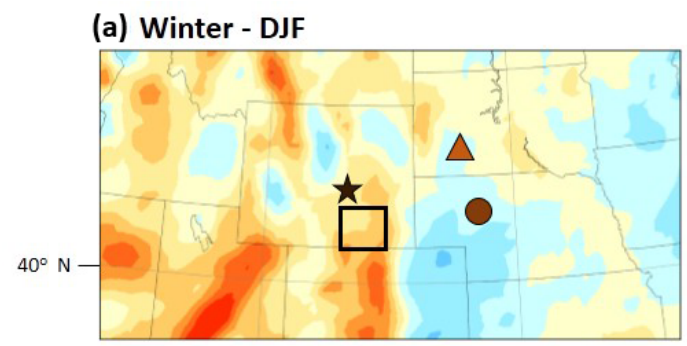

(b) Spring - MAM

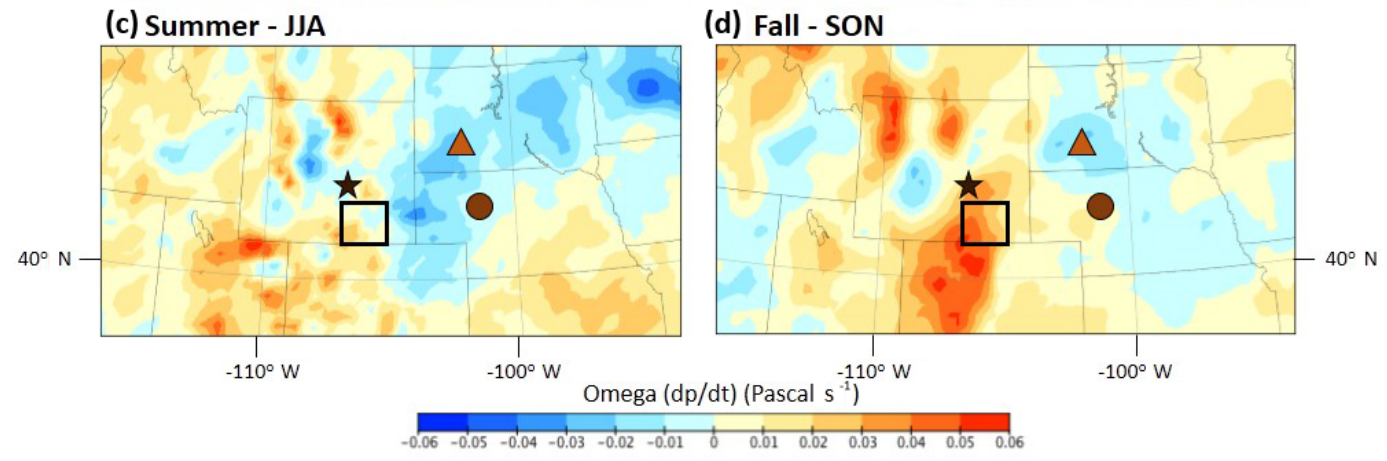

Figure 9. Composite-anomaly maps for 500 mbar omega (vertical velocity) during (a) winter (DJF); (b) spring (MAM); (c) summer (JJA); and (d) the fall (SON). Positive values (warm colours) for omega indicate enhanced sinking motions (suppress precipitation). Negative values (cool colours) indicate enhanced rising motions (enhanced precipitation). The black box denotes the study site, Long Lake in the Medicine Bow Mountains of southeastern, Wyoming. The black star denotes the Ferris and Casper dune fields; the orange triangle denotes the White River Badlands dunes; and the brown circle denotes the Nebraska Hills sand dunes.

\subsection{Limitations of the modern climate analogue technique}

The modern climate analogue is beneficial in that it offers a way of understanding synoptic processes in the past (Barry, 1981). However, it does have a few limitations. The first and foremost is the assumption that the analogues used in this study represent megadrought conditions that persisted on decadal-to-centennial timescales. The current state of research is in general agreement that anomalous and persistent high-pressure ridges over the Great Plains are one of the most common contributors to drought (Basara et al., 2013). Persistent high-pressure ridges support subsidence (e.g. sinking vertical motions) which suppresses precipitation. Additionally, the clockwise flow of air associated with high-pressure ridges prevents the typical southward movement of cold fronts from Canada which serve to organize spring rains, block delivery of moisture from the Gulf of Mexico, and inhibit convective thunderstorms which would normally contribute to summer precipitation in the Great Plains region (Hoerling et al., 2014). The role of anticyclones during drought has been observed in decadal to- multidecadal model simulations (Herweijer et al., 2006). In addition enhanced anticyclonic circulation over the Great Plains was found to be a prominent feature causing mid-Holocene droughts in the region (Diffenbaugh et al., 2006). Thus, we presume the scenario presented in this study may be representative of droughts on longer timescales. Yet, we acknowl- edge that slow ocean dynamics and Pacific and Atlantic teleconnections, which are important components involved with Great Plains drought, may have been factors involved with megadroughts in the past. Yet, our analogues may not be representative of such dynamics, just as those teleconnections may lack mechanistic linkages. While it has been suggested from both modern observation and modelled data that a relationship exists between SSTs and drought (Trenberth et al., 1988; Palmer and Brankovic, 1989; Kalnay et al., 1990; Schubert et al., 2004; Basara et al., 2013; Cook et al., 2016), Hoerling et al. (2014) found weak evidence to support SST as a strong forcing on major droughts in the central Great Plains because droughts occurred in each phase of ENSO. As the relationship between Pacific and Atlantic teleconnections and slow ocean dynamics are not very well understood (Basara et al., 2013), our study does not investigate nor address internal variability or SSTs, both of which have been shown to contribute to droughts in these regions (Schubert et al., 2004; Herweijer et al., 2006). Future opportunities to test the synoptic drivers of prolonged drought presented here include data-model comparisons and regional climate modelling to investigate whether the analogues and the resulting climate scenario are reflective of decadal-to-centennial megadrought conditions. 
(a) Winter - DJF

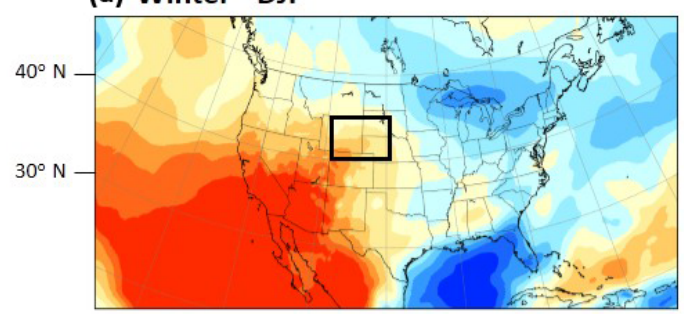

(c) Summer - JJA

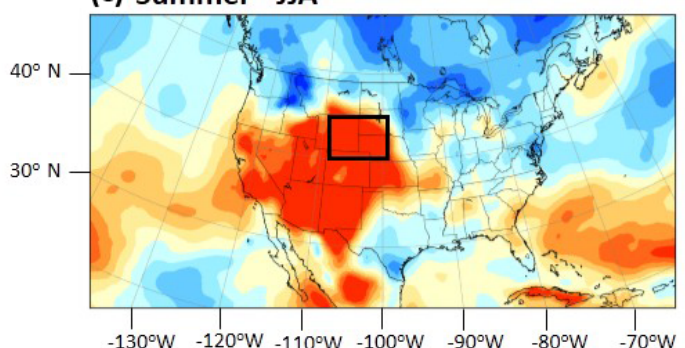

(b) Spring - MAM

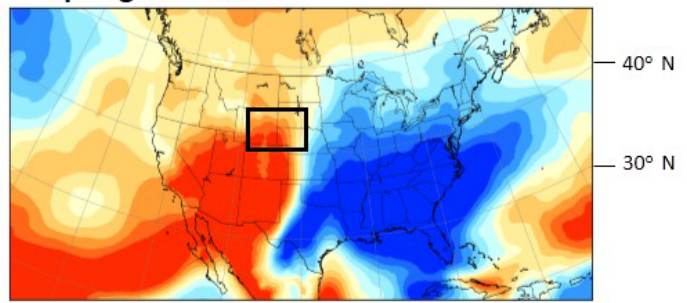

(d) Fall - SON

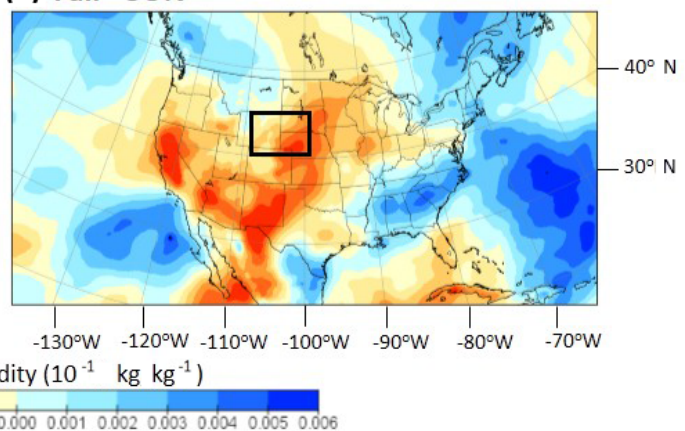

Figure 10. Composite-anomaly maps for 850 mbar specific humidity during (a) winter (DJF); (b) spring (MAM); (c) summer (JJA); and (d) fall (SON). Positive values (cool colours) for 850 mbar specific humidity indicate wetter-than-normal conditions in the atmosphere. Negative values (warm colours) indicate drier-than-normal conditions. The black box denotes the study region.

\section{Conclusion}

Paleoecological reconstructions are valuable for understanding how ecosystems and disturbances respond to both gradual and abrupt changes in climate. However, proxy evidence preserved in sedimentary records are unable to record climatic mechanisms that caused the ecological responses. Using the modern climate analogue technique, our results offer potential climatic mechanisms that explains how persistent drought may have affected the vegetation composition at Long Lake, Wyoming, as well as impacted dune-stabilizing vegetation across the western Great Plains. Specifically, the modern climate analogues illustrate how drought conditions prevailed during the 2002/2012 growing season. Unique to all seasons are the anomalous high-pressure ridges positioned over the central region of the US which coincidently have been associated with the most recent droughts of the 20th century. In the spring, as suggested by Schmeisser et al. (2010), higher-than-normal geopotential heights over the southern US and central Great Plains region resulted in the southwesterly component of flow, which inhibited moisture transport to the study region. As late-spring to early-summer precipitation is crucial for the region, the scenario presented by the 2002/2012 analogues would mechanistically explain how persistently dry conditions could result in the reduction of dune-stabilizing vegetation across the western Great Plains region identified by Stokes and Gaylord (1993), Halfen et al. (2010), Rawling et al. (2003), Schmieder et al. (2011), Mason et al. (2004), Goble et al. (2004), Stokes and Swinehart (1997), Loope et al. (1995), Ahlbrandt et al. (1983), and Madole (1995). The 2002/2012 analogues also illustrate an anticyclonic feature over the north-central Great Plains during the summer which resulted in an easterly to southeasterly component of flow, prolonging drought conditions in the region (Chang and Smith, 2001). If the present scenario of persistently dry conditions existed between 4300 and $4100 \mathrm{cal}$ yr BP, the 2002/2012 analogues also offer a mechanistic explanation that supports the surface paleoecological responses identified by Carter et al. (2013), i.e. the Populus period. The 2002/2012 analogues support the working hypothesis that due to the geographical proximity of the CRM (i.e. Long Lake, Wyoming) to the western Great Plains, synoptic processes causing widespread drought in the region influence the CRM. However, we acknowledge that the present study assumes that the 2002/2012 analogues are reflective of megadrought conditions that persist on decadalto-centennial timescales. Future data-model comparisons should investigate whether the synoptic processes presented in this study hold true on decadal-to-centennial timescales.

Droughts such as the one centred on 4200 cal yr BP, as well as several droughts in the 13th and 16th centuries were more severe and of longer duration than the more recent droughts of the 20th century (Woodhouse and Overpeck, 1998). Understanding the climate processes associated with modern drought provide better insight into past drought variability and the mechanisms that caused megadroughts evident in paleoecological records. This study demonstrated the benefits of applying a modern climate analogue technique to the pa- 
leoecological reconstruction from the CRM and the western Great Plains in order to better understand the potential climatic mechanisms that impacted ecological changes.

Data availability. Modern climate analogue years were selected based on NOAA/NCDC Wyoming Climate Division 10, Wyoming Climate Division 8, South Dakota Climate Division 5, and Nebraska Climate Division 2 from the Earth System Research Laboratory, Physical Sciences Division of NOAA (https://www.esrl.noaa.gov/psd/data/timeseries/, Earth System Research Laboratory, 2018). Surface and atmospheric variables used in the composite-anomaly analysis are available through the Earth System Research Laboratory, Physical Sciences Division of NOAA (https://www.ncdc.noaa.gov/data-access/model-data/ model-datasets/north-american-regional-reanalysis-narr,

Mesinger et al., 2006). Pollen and charcoal data have been uploaded to the Neotoma Paleoecology Database web page: https://www.neotomadb.org/groups/category/pollen (Carter et al., 2017a); https://apps.neotomadb.org/Explorer/?datasetid=_24878 (Carter et al., 2017a). Pollen and charcoal data are interpreted at $1 \mathrm{~cm}$ resolution between depths 94 and $176 \mathrm{~cm}$, as described by Carter et al. (2017a). Dune reactivation data were graciously obtained from the Supplement data uploaded by Halfen and Johnson (2013).

Author contributions. VAC and JJS obtained funding to support the research; VAC and JJS collected the data; VAC, JJS, and JP analysed the data; JP conducted the statistical analysis; VAC led the manuscript writing; JJS and JP edited the manuscript during all phases.

Competing interests. The authors declare that they have no conflict of interest.

Special issue statement. This article is part of the special issue "Global Challenges for our Common Future: a paleoscience perspective" - PAGES Young Scientists Meeting 2017. It is a result of the 3rd Young Scientists Meeting (YSM), Morillo de Tou, Spain, 7-9 May 2017.

Acknowledgements. We would like to thank Andrea Brunelle and the RED Lab, as well as the National Science Foundation, for assisting and funding this research. Funding was supported by NSF Doctoral Dissertation Improvement Grant no. 1558289. We would also like to thank the Young Scientists Meeting (YSM) and PAGES for the invitation to contribute in this special issue. Lastly, we are indebted to the five reviewers and editor. Their feedback and suggestions greatly improved the manuscript.

Edited by: Heather Plumpton

Reviewed by: five anonymous referees

\section{References}

Adams, D. K. and Comrie, A. C.: The North American monsoon, B. Am. Meteorol. Soc., 78, 2197-2213, https://doi.org/10.1175/15200477(1997)078<2197:TNAM>2.0.CO;2, 1997.

Ahlbrandt, T. S., Swinehart, J. B., and Maroney, D. G.: The dynamic Holocene dune fields of the Great Plains and Rocky Mountain basins, USA, in: Eolian Sediments and Processes, edited by: Brookfield, M. E. and Ahlbrandt, T. S., Elsevier, New York, 379406, 1983.

Allen, A. M., Hostetler, S. W., and Alder, J. R.: Analysis of the present and future winter Pacific-North American teleconnection in the ECHAM5 global and RegCM3 regional climate models, Clim. Dynam., 42, 1671-1682, https://doi.org/10.1007/s00382013-1910-x, 2014.

An, C. B., Tang, L., Barton, L., and Chen, F. H.: Climate change and cultural response around $4000 \mathrm{calyr}$ B.P. in the western part of Chinese Loess Plateau, Quaternary Res., 63, 347-352, https://doi.org/10.1016/j.yqres.2005.02.004, 2005.

Anderegg, L. D. L., Anderegg, W. R. L., Abatzoglou, J., Hausladen, A. M., and Berry, J. A.: Drought characteristics" role in widespread aspen forest mortality across Colorado, USA, Glob. Change Biol., 19, 1526-1537, https://doi.org/10.1111/gcb.12146, 2013a.

Anderegg, W. R. L., Plavcová, L., Anderegg, L. D. L., Hacke, U. G., Berry, J. A., and Field, C. B.: Drought's legacy: multiyear hydraulic deterioration underlies widespread aspen forest die-off and portends increased future risk, Glob. Change Biol., 19, 11881196, https://doi.org/10.1111/gcb.12100, 2013b.

Anderson, L.: Rocky Mountain hydroclimate: Holocene variability and the role of insolation, ENSO, and the North American Monsoon, Global Planet. Change, 92-93, 198-208, https://doi.org/10.1130/G31575.1, 2012.

Anderson, L., Brunelle, A., and Thompson, R. S.: A multi-proxy record of hydroclimate, vegetation, fire, and post-settlement impacts for a subalpine plateau, central Rocky Mountains, USA, Holocene, 25, 1-12, https://doi.org/10.1177/0959683615574583, 2015.

Anderson, L., Berkelhammer, M., Barron, J. A., Steinman, B. A., Finney, B. P., and Abbott, M. B.: Lake oxygen isotopes as recorders of North American Rocky Mountain hydroclimate: Holocene patterns and variability at multi-decadal to millennial time scales, Global Planet. Change, 137, 131-148, https://doi.org/10.1016/j.gloplacha.2015.12.021, 2016.

Barron, J. A. and Anderson, L: Enhanced Late Holocene ENSO/PDO expression along the margins of the eastern North Pacific, Quatern. Int., 235, 3-12, https://doi.org/10.1016/j.quaint.2010.02.026, 2010.

Barry, R. G.: Atmospheric circulation and climatic change, I. Approaches to paleoclimatic reconstruction, in: Climatic Variations and Variability: Facts and Theories, edited by: Berger, A., Reidel, Dordrecht, 333-345, 1981.

Barry, R. G. and Carleton, A. M.: Synoptic and dynamic climatology, Routledge Psychology Press, London England, 2001.

Basara, J. B., Maybourn, J. N., Pierano, C. M., Tate, J. E., Brown, P. J., Hoey, J. D., and Smith, B. R.: Drought and associated impacts in the Great Plains of the United States - A review, Int. J. Geo- 
sciences, 4, 72-81, https://doi.org/10.4236/ijg.2013.46A2009, 2013

Bernal, J. P., Lachniet, M., McCulloch, M., Mortimer, G., Morales, P., and Cienfuegos, E.: A speleothem record of Holocene climate variability from southwestern Mexico, Quaternary Res., 75, 104113, https://doi.org/10.1016/j.yqres.2010.09.002, 2011.

Booth, R. K., Jackson, S. T., Forman, S. L., Kutzbach, J. E., Bettis, E. A., Kreigs, J., and Wright, D. K.: A severe centennialscale drought in the mid-continental North America 4200 years ago and apparent global linkages, Holocene, 15, 321-328, https://doi.org/10.1191/0959683605hl825ft, 2005.

Carter, V. A., Brunelle, A., Minckley, T. A., Dennison, P. E., and Power, M. J.: Regionalization of fire regimes in the Central Rocky Mountains, USA, Quaternary Res., 80, 406-416, https://doi.org/10.1016/j.yqres.2013.07.009, 2013.

Carter, V. A.: The role of climate variability and disturbances on forest ecology in the intermountain west, $\mathrm{PhD}$ dissertation, $\mathrm{De}$ partment of Geography, University of Utah, 2016.

Carter, V. A., Brunelle, A., Minckley, T. A., Shaw, J. D., DeRose, R. J., and Brewer, S.: Climate variability and fire effects on quaking aspen in the central Rocky Mountains, USA, J. Biogeogr., 44, 1280-1293, https://doi.org/10.1111/jbi.12932, 2017a.

Carter, V. A., Power, M. J., Lundeen, Z. J., Morris, J. L., Petersen, K. L., Brunelle, A., Anderson, R. S., Shinker, J. J., Turney, L., Koll, R., and Bartlein, P. J.: A 1500-year synthesis of wildfire activity stratified by elevation from the US Rocky Mountains, Quatern. Int., 448, 107-119, https://doi.org/10.1016/j.quaint.2017.06.051, 2017b.

Cayan, D. R.: Interannual climate variability and snowpack in the western United States, J. Climate, 9, 928-948, https://doi.org/10.1175/15200442(1996)009<0928:ICVASI>2.0.CO;2, 1996.

Chang, F.-C. and Smith, E. A.: Hydrological and dynamical characteristics of summertime droughts over US Great Plains, J. Climate, 14, 2296-2316, https://doi.org/10.1175/15200442(2001)014<2296:HADCOS>2.0.CO;2, 2001.

Coats, S., Smerdon, J. E., Seager, R., Cook, B. I., and GonzalezRouco, J. F.: Megadroughts in Southwestern North America in ECHO-G Millennial Simulations and Their Comparisons to Proxy Drought Reconstructions, J. Climate, 26, 7635-7649, https://doi.org/10.1175/JCLI-D-12-00603.1, 2013.

Cook, E. R., Woodhouse, C. A., Eakin, C. M., Meko, D. M., and Stahle, D. W.: Long-term aridity changes in the western United States, Science, 306, 1015-1018, https://doi.org/10.1126/science.1102586, 2004.

Cook, E. R., Seager, R., Heim Jr., R. R., Vose, R. S., Herweijer, C., and Woodhouse, C.: Megadroughts in North America: Placing IPCC projections of hydroclimatic change in a long-term palaeoclimate context, J. Quaternary Sci., 25, 48-61, https://doi.org/10.1002/jqs.1303, 2010.

Cook, B. I., Cook, E. R., Smerdon, J. E., Seager, R., Williams, A. P., Coats, S., Stahle, D. W., and Villanueva Díaz, J.: North American megadroughts in the Common Era: reconstructions and simulations, WIREs Clim. Change., 7, 411-432, https://doi.org/10.1002/wcc.394, 2016.

Dean, W.: Rates, timing, and cyclicity of Holocene eolian activity in north-central United States: evidence from varved lake sediments, Geology, 25, 331-334, https://doi.org/10.1130/00917613(1997)025<0331:RTACOH>2.3.CO;2, 1997.
deMenocal, P. B.: Cultural responses to climate change during the Late Holocene, Science, 292, 667-673, https://doi.org/10.1126/science.1059188, 2001.

Dettinger, M. D., Cayan, D., Diaz, H., and Meko, D.: North-south precipitation in western North America on interannual-to-decadal timescales, J. Climate, 11, 3095-3111, https://doi.org/10.1175/15200442(1998)011<3095:NSPPIW>2.0.CO;2, 1998.

Diaz, H. F. and Andrews, J. T.: Analysis of the spatial pattern of July temperature departures (1943-1972) over Canada and estimates of the $700 \mathrm{mb}$ mid-summer circulation during middle and late Holocene, Int. J. Climatol., 2, 251-265, https://doi.org/10.1002/joc.3370020304, 1982.

Diaz, H. F.: Drought in the United States: Some aspects of major dry and wet periods in the contiguous United States, 1895-1981, J. Appl. Meteorol., 22, 3-16, 1983.

Diffenbaugh, N. S., Ashfaq, M., Shuman, B., Williams, J. W., and Bartlein, P. J.: Summer aridity in the United States: Response to the mid-Holocene changes in insolation and sea surface temperature, Geophys. Res. Lett., 33, L22712, https://doi.org/10.1029/2006GL028012, 2006.

Dominguez, F., Camilo Villegas, J., and Breshears, D. D.: Spatial extent of North American Monsoon: Increased cross-regional linkages via atmospheric pathways, Geophys. Res. Lett., 36, L07401, https://doi.org/10.1029/2008GL037012, 2009.

Earth System Research Laboratory, Physical Sciences Division of NOAA, NOAA/NCDC monthly/seasonal mean time series from US Climate Division Dataset, https://www.esrl.noaa.gov/ psd/data/timeseries/, last accessed: 26 July 2018.

Edwards, M. E., Mock, C. J., Finney, B. P., Barber, V. A., and Bartlein, P. J.: Potential analogues for paleoclimatic variations in eastern interior Alaska during the past 14,000 yr: Atmospheric circulation controls of regional temperature and moisture response, Quaternary Sci. Rev., 20, 189-202, https://doi.org/10.1016/S0277-3791(00)00123-2, 2001.

Ely, L. L.: Response of extreme floods in the southwestern United States to climatic variations in the late Holocene, Geomorphology, 19, 175-201, https://doi.org/10.1016/S0169555X(97)00014-7, 1997.

Fischer, H., Meissner, K. J., Mix, A. C., Abram, N. J., Austermann, J., Brovkin, V., Capron, E., Colombaroli, D., Daniau, A.L., Dyez, K. A., Felis, T., Finkelstein, S. A., Jaccard, S. L., McClymont, E. L., Rovere, A., Sutter, J., Wolff, E. W., Affolter, S., Bakker, P., Ballesteros-Cánova, J. A., Barbante, C., Caley, T., Carlson, A. E., Churakova (Sidorova), O., Cortese, G., Cumming, B. F., Davis, B. A. S., de Vernal, A., EmileGeay, J., Fritz, S. C., Gierz, P., Gottschalk, J., Holloway, M. D., Joos, F., Kucera, M., Loutre, M.-F., Lunt, D. J., Marcisz, K., Marlon, J. R., Martinez, P., Masson-Delmotte, V., NehrbassAhles, C., Otto-Bliesner, B. L., Raible, C. C., Risebrobakken, B., Sánchez Goñi, M. F., Saleem Arrigo, J., Sarnthein, M., Sjolte, J., Stocker, T. F., Velasquez Alvárez, P. A., Tinner, W., Valdes, P. J., Vogel, H., Wanner, H., Yan, Q., Yu, Z., Ziegler, M., and Zhou, L.: Palaeoclimate constraints on the impact of $2{ }^{\circ} \mathrm{C}$ anthropogenic warming and beyond, Nat. Geosci., 11, 474-485, https://doi.org/10.1038/s41561-018-0146-0, 2018.

Fisher, D., Osterberg, E., Dyke, A., Dahl-Jensen, D., Demuth, M., Zdanowicz, C., Bourgeois, J., Koerner, R. M., Mayewski, P., Wake, C., Kreutz, K., Steig, E., Zheng, J., 
Yalcin, K., Goto-Azuma, K., Luckman, B., and Rupper, S.: The Mt. Logan Holocene-late Wisconsinan isotope record: tropical Pacific-Yukon connections, Holocene, 18, 667-677, https://doi.org/10.1177/0959683608092236, 2008.

Garfin, G., Jardine, A., Merideth, R., Black, M., and LeRoy, S.: Assessment of Climate Change in the Southwest United States: A Report Prepared for the National Climate Assessment, A report by the Southwest Climate Alliance, Island Press, Washington, DC, 2013.

Goble, R. J., Mason, J. A., Loope, D. B., and Swinehart, J. B.: Optical and radiocarbon ages of stacked paleosolo and dune sands in the Nebraska Sand Hills, USA, Quaternary Sci. Rev., 23, 11731182, https://doi.org/10.1016/j.quascirev.2003.09.009, 2004.

Grimm, E. C., Donovan, J. J., and Brown, K. J.: A highresolution record of climate variability and landscape response from Kettle Lake, northern Great Plains, North America, Quaternary Sci. Rev., 30, 2626-2650, https://doi.org/10.1016/j.quascirev.2011.05.015, 2011.

Halfen, A. F., Fredlund, G. G., and Mahen, S. A.: Holocene stratigraphy and chronology of the Casper Dune Field, Casper, Wyoming, USA, Holocene, 20, 773-783, https://doi.org/10.1177/0959683610362812, 2010.

Halfen, A. F. and Johnson, W. C.: A review of Great Plains dune field chronologies, Aeolian Res., 10, 135-160, https://doi.org/10.1016/j.aeolia.2013.03.001, 2013.

Hanna, P. and Kulakowski, D.: The influences of climate on aspen dieback, Forest Ecol. Manag., 274, 91-98, https://doi.org/10.1016/j.foreco.2012.02.009, 2012.

Herweijer, C., Seager, R., and Cook, E. R.: North American droughts of the mid to late nineteenth century: a history, simulation and implication for Mediaeval drought, Holocene, 16, 159171, https://doi.org/10.1191/0959683606h1917rp, 2006.

Heyer, J. P., Brewer, S., and Shinker, J. J.: Using high-resolution reanalysis data to explore localized western North America hydroclimate relationships with ENSO, J. Climate, 30, 1395-5417, https://doi.org/10.1175/JCLI-D-16-0476.1, 2017.

Hoerling, M., Eischeid, J., Kumar, A., Leung, R., Mariotti, A., Mo, K., Schubert, S., and Seager, R.: Causes and predictability of the 2012 Great Plains drought, B. Am. Meteorol. Soc., 95, 269-282, https://doi.org/10.1175/BAMS-D-13-00055.1, 2014.

Hogg, E. H., Brandt, J. P., and Michaelin, M.: Impacts of regional drought on the productivity, dieback, and biomass of Canadian aspen forests, Can. J. Forest Res., 38, 1373-1384, https://doi.org/10.1139/X08-001, 2008.

IPCC: Climate Change 2014: Synthesis Report, in: Contribution of Working Groups I, II and III to the Fifth Assessment Report of the Intergovernmental Panel on Climate Change, edited by: Core Writing Team, Pachauri, R. K., and Meyer, L. A., Geneva, Switzerland, IPCC, 2014.

Kalnay, E., Kanamitsu, M., and Baker, W. E.: Global numerical weather prediction at the National Meteorological Center, B. Am. Meteorol. Soc., 71, 1410-1428, https://doi.org/10.1175/15200477(1990)071<1410:GNWPAT>2.0.CO;2, 1990.

Kashian, D. M., Romme, R. H., and Regan, C. M.: Reconciling divergent interpretations of quaking aspen decline on the Northern Colorado Front Range, Ecol. Appl., 17, 1296-1311, https://doi.org/10.1890/06-1431.1, 2007.
Leathers, D. J., Yarnal, B., and Palecki, M. A.: The Pacific/North American teleconnection pattern and United States climate. Part I: regional temperature and precipitation associations, J. Climate, 4, 517-528, https://doi.org/10.1175/15200442(1991)004<0517:TPATPA>2.0.CO;2, 1991.

Liu, Z., Yoshimura, K., Bowen, G. J., Buenning, N. H., Risi, C., Welker, J. M., and Yuan, F.: Paired oxygen isotope record reveal modern North American atmospheric dynamics during the Holocene, Nat. Commun., 5, 1-7, https://doi.org/10.1038/ncomms4701, 2014.

Loope, D. B., Swinehart, J. B., and Mason, J. P.: Dunedammed wetlands and buried paleovalleys of the $\mathrm{Ne}$ braska Sand Hills: intrinsic vs. climatic controls on the accumulation of lake and marsh sediments, Geol. Soc. Am. Bull., 107, 396-406, https://doi.org/10.1130/00167606(1995)107<0396:DDPOTN>2.3.CO;2, 1995.

Lundeen, Z., Brunelle, A., Burns, S. J. Polyak, V., and Asmerom, Y.: A speleothem record of Holocene paleoclimate from the northern Wasatch Mountains, southeast Idaho, USA, Quatern. Int., 310, 83-95, https://doi.org/10.1016/j.quaint.2013.03.018, 2013.

Madole, R. F.: Spatial and temporal patterns of late Quaternary eolian deposition, eastern Colorado, USA, Quaternary Sci. Rev., 14, 155-177, https://doi.org/10.1016/0277-3791(95)00005-A, 1995.

Mason, J. A., Swinehart, J. B., Goble, R. J., and Loope, D. B.: Late-Holocene dune activity linked to hydrological drought, Nebraska Sand Hills, USA, Holocene, 14, 209-217, https://doi.org/10.1191/0959683604hl677rp, 2004.

Maurer, M. K., Menounos, B., Luckman, B. H., Osborn, G., Clague, J. J., Beedle, M. J., Smith, R., and Atkinson, N.: Late Holocene glacier expansion in the Cariboo and northern Rocky Mountains, British Columbia, Canada, Quaternary Sci. Rev., 51, 7180, https://doi.org/10.1016/j.quascirev.2012.07.023, 2012.

Mayer, J. H. and Mahan, S. A.: Late Quaternary stratigraphy and geo- chronology of the western Killpecker Dunes, Wyoming, USA, Quaternary Res., 61, 72-84, https://doi.org/10.1016/j.yqres.2003.10.003, 2004.

Menounos, B., Clague, J. J., Osborn, G., Luckman, B. H., Lakeman, T. R., and Minkus, R.: Western Canadian glaciers advance in concert with climate change circa $4.2 \mathrm{ka}$, Geophys. Res. Lett., 35, L07501, https://doi.org/10.1029/2008GL033172, 2008.

Mensing, S. A., Sharpe, S. E., Tunno, I., Sada, D. W., Thomas, J. M., Starratt, S., and Smith, J.: The Late Holocene Dry Period: Multiproxy evidence for an extended drought between 2800 and $1850 \mathrm{calyr} \mathrm{BP}$ across the central Great Basin, USA, Quaternary Sci. Rev., 78, 266-282, https://doi.org/10.1016/j.quascirev.2013.08.010, 2013.

Mesinger, F., DiMego, G., Kalnay, E., Mitchell, K., Shafran, P. C., Ebisuzaki, W., Jović, D., Woollen, J., Rogers, E., Berbery, E. H., Ek, M. B., Fan, Y., Grumbine, R., Higgins, W., Li, H., Lin, Y., Manikin, G., Parrish, D., and Shi, W.: North American regional analysis, B. Am. Meteorol. Soc., 87, 343-360, https://doi.org/10.1175/BAMS-87-3-343, 2006.

Metcalfe, S. E., Barron, J. A., and Davies, S. J.: The Holocene history of the North American Monsoon: "known knowns" and "known unknowns" in understanding its spatial and temporal complexity, Quaternary Sci. Rev., 120, 1-27, https://doi.org/10.1016/j.quascirev.2015.04.004, 2015. 
Miao, X., Mason, J. A., Swinehart, J. B., Loope, D. B., Hanson, P. R., Goble, R. J., and Liu, X.: A 10000 year record of dune activity, dust storms, and severe drought in the central Great Plains, Geology, 35, 119-122, https://doi.org/10.1130/G23133A.1, 2007.

Mock, C. J. and Bartlein, P. J.: Spatial variability of late-Quaternary paleoclimates in the western United States, Quaternary Res., 44, 425-433, https://doi.org/10.1006/qres.1995.1087, 1995.

Mock, C. J.: Climatic controls and spatial variations of precipitation in the western United States, J. Climate, 9, 1111-1124, https://doi.org/10.1175/15200442(1996)009<1111:CCASVO>2.0.CO;2, 1996.

Mock, C. J. and Anderson, P. M.: Some perspectives on the late Quaternary paleoclimate of Beringia, in: Proceedings of the Thirteenth Annual Pacific Climate (PACLIM) Workshop, edited by: Isaacs, C. M. and Tharp, V., Technical Report 53 of the Interagency Ecological Program, California Department of Water Resources, 193-200, 1997.

Mock, C. J. and Brunelle-Daines, A. R.: A modern analogue of western United States summer paleoclimate at 6,000 years Before Present, Holocene, 9, 541-545, https://doi.org/10.1191/095968399668724603, 1999.

Mock, C. J. and Shinker, J. J.: Modern analogue approaches in paleoclimatology, in: The Encyclopedia of Quaternary Science, edited by: Elias, S. A., Elsevier, Amsterdam, the Netherlands, 102-112, 2013.

Morris, J. L., Brunelle, A., Munson, A. S., Spencer, J., and Power, M. J.: Holocene vegetation and fire reconstructions from the Aquarius Plateau, Utah, USA, Quatern. Int., 310, 111-123, https://doi.org/10.1016/j.quaint.2012.10.055, 2013.

Müller, W. A. and Roeckner, E.: ENSO impact on midlatitude circulation patterns in future climate change projections, Geophys. Res. Lett., 33, 1-4, https://doi.org/10.1029/2005GL025032, 2006.

Namias, J.: Spring and Summer 1988 Drought over the Contiguous United States - Causes and Prediction, J. Climate, 4, 54-65, https://doi.org/10.1175/15200442(1991)004<0054:SASDOT>2.0.CO;2, 1991.

Notaro, M., Wang, W.-C., and Gong, W.: Model and observational analysis of the Northeast U.S. regional climate and its relationship to the PNA and NAO patterns during early winter, Mon. Weather Rev., 134, 3479-3505, https://doi.org/10.1175/MWR3234.1, 2006.

NRCS: unpublished data, available at: https://www.wcc.nrcs.usda. gov, last access: 13 June 2012.

Overpeck, J. T., Webb III, T., and Prentice, I. C.: Quantitative interpretation of fossil pollen spectra: dissimilarity coefficients and the method of modern analogs, Quaternary Res., 23, 87-108, https://doi.org/10.1016/0033-5894(85)90074-2, 1985.

Palmer, T. N. and Branković, Č: The 1988 US drought linked to anomalous sea surface temperature, Nature, 338, 54-57, https://doi.org/10.1038/338054a0, 1989.

Rawling III, J. E., Fredlund, G. G., and Mahan, S. A.: Aeolian cliff-top deposits and buried soils in the White River Badlands, South Dakota, USA, Holocene, 13, 129-129, https://doi.org/10.1191/0959683603hl601rr, 2003.

Rehfeldt, G. E., Ferguson, D. E., and Crookston, N. L.: Aspen, climate, and sudden aspen decline in west- ern USA, Forest Ecol. Manag., 258, 2352-2364, https://doi.org/10.1016/j.foreco.2009.06.005, 2009.

Salzer, M. W., Bunn, A. G., Graham, N. E., and Hughes, M. K.: Five millennia of paleotemperature from tree-rings in the Great Basin, USA, Clim. Dynam., 42, 1517-1526, https://doi.org/10.1007/s00382-013-1911-9, 2014.

Schmieder, J: The Nebraska Sand Hills - Mid- to Late-Holocene Drought Variation and Landscape Stability Based on HighResolution Lake Sediment Records, PhD dissertation, Earth and Atmospheric Sciences, University of Nebraska - Lincoln, 2009.

Schmieder, J., Fritz, S. C., Swinehart, J. B., Shinneman, A. L. C., Wolfe, A. P., Miller, G., Daniels, N., Jacobs, K. C., and Grimm, E. C.: A regional-scale climate reconstruction of the last 4000 years from lakes in the Nebraska Sand Hills, USA, Quaternary Sci. Rev., 30, 1797-1812, https://doi.org/10.1016/j.quascirev.2011.04.011, 2011.

Schmeisser, R. L., Loope, D. B., and Mason, J. A.: Modern and late Holocene wind regimes over the Great Plains (central U.S.A.), Quaternary Sci. Rev., 29, 554-566, https://doi.org/10.1016/j.quascirev.2009.11.003, 2010.

Schubert, S. D., Suarez, M. J., and Pegion, P. J.: Causes of long-term drought in the U.S. Great Plains, J. Climate, 17, 485-503, https://doi.org/10.1175/15200442(2004)017<0485:COLDIT>2.0.CO;2, 2004.

Shabber, A. and Khandekar, M.: The impact of el NinoSouthern oscillation on the temperature field over Canada: Research note, Atmos. Ocean., 34, 401-416, https://doi.org/10.1080/07055900.1996.9649570, 1996.

Shinker, J. J., Bartlein, P. J., and Shuman, B.: Synoptic and dynamic climate controls of North American midcontinental aridity, Quaternary Sci. Rev., 25, 1401-1417, https://doi.org/10.1016/j.quascirev.2005.12.012, 2006.

Shinker, J. J.: Visualizing spatial heterogeneity of Western United States climate variability, Earth Interact., 14, 1-15, https://doi.org/10.1175/2010EI323.1, 2010.

Shinker, J. J.: Climatic controls of hydrologic extremes in southinterior intermountain west of Colorado, U.S.A. Rocky Mount, Geology, 49, 51-60, 2014.

Shulmeister, J. and Lees, B. G.: Australasian evidence for mid-Holocene climate change implies precessional control of Walker Circulation in the Pacific, Quatern. Int., 57/58, 81-91, https://doi.org/10.1016/S1040-6182(98)00052-4, 1995.

Shuman, B. N., Henderson, A. K., Colman, S. M., Stone, J. R., Fritz, S. C., Stevens, L. R., Power, M. J., and Whitlock, C.: Holocene lake-level trends in the Rocky Mountains, USA, Quaternary Sci. Rev., 28, 1861-1879, https://doi.org/10.1016/j.quascirev.2009.03.003, 2009.

Shuman, B. N., Carter, G. E., Hougardy, D. D., Powers, K., and Shinker, J. J.: A north-south moisture dipole at multi-century scales in the central and southern Rocky Mountains, USA during the late Holocene, Rocky Mount, Geology, 49, 33-49, https://doi.org/10.2113/gsrocky.49.1.33, 2014.

Shuman, B. N., Pribyl, P., and Buettner, J.: Hydrologic changes in Colorado during the mid-Holocene and Younger Dryas, Quaternary Res., 84, 187-199, https://doi.org/10.1016/j.yqres.2015.07.004, 2015.

Shuman, B. N. and Marsicek, J.: The structure of Holocene climate change in mid-latitude North America, Quaternary Sci. Rev., 
141, 38-51, https://doi.org/10.1016/j.quascirev.2016.03.009, 2016.

Sridhar, V., Loope, D. B., Swinehart, J. B., Mason, J. A., Oglesby, R. J., and Rowe, C. M.: Large wind shift on the Great Plains during the Medieval Warm Period, Science, 313, 345-347, https://doi.org/10.1126/science.1128941, 2006.

Steinman, B. A., Pompeani, D. P., Abbott, M. B., Ortiz, J. D., Stansell, N. D., Finkenbinder, M. S., Mihindukulasooriya, L. N., and Hillman, A. L.: Oxygen isotope records of Holocene climate variability in the Pacific Northwest, Quaternary Sci. Rev., 142, 40-60, https://doi.org/10.1016/j.quascirev.2016.04.012, 2016.

Stokes, S. and Gaylord, D. R.: Optical dating of Holocene dune sands in the Ferris Dune Field, Wyoming, Quaternary Res., 39, 274-281, https://doi.org/10.1006/qres.1993.1034, 1993.

Stokes, S. and Swinehart, J. B.: Middle- and late-Holocene dune reactivation in the Nebraska Sand Hills, USA, Holocene, 7, 263272, https://doi.org/10.1177/095968369700700302, 1997.

Taschetto, A. S. and England, M. H.: El Niño Modoki impacts on Australian rainfall, J. Climate, 22, 3167-3174, https://doi.org/10.1175/2008JCLI2589.1, 2009.

Trenberth, K. E., Branstator, G. W., and Arkin, P. A.: Origins of the 1988 North American Drought, Science, 242, 1640-1645, https://doi.org/10.1126/science.242.4886.1640, 1998.

Wallace, J. M. and Gutzler, D. S.: Teleconnections in the geopotential height field during the Northern Hemisphere winter, Mon. Weather. Rev., 109, 784-812, https://doi.org/10.1175/15200493(1981)109<0784:TITGHF>2.0.CO;2, 1981.

Wanner, H., Mercolli, L., Grosjean, M., and Ritz, S. P: Holocene climate variability and change; a data-based review, J. Geol. Soc., 172, 254-263, https://doi.org/10.1144/jgs2013-101, 2015.

Weiss, H.: Global megadrought, societal collapse and resilience at 4.2-3.9 ka BP across the Mediterranean and west Asia, PAGES Magazine, 24, 62-63, https://doi.org/10.22498/pages.24.2.62, 2016.

Weiss, H.: 4.2 ka BP Megadrought and the Akkadian Collapse, in: Megadrought and Collapse: From Early Agriculture to Angkor, edited by: Weiss, H., University Press, Oxford, UK, 93-160, 2017 .
Weiss, H.: Megadrought, Collapse, and Causality, in: Megadrought and Collapse: From Early Agriculture to Angkor, edited by: Weiss, H., University Press, Oxford, UK, 1-31, 2017 b.

Wise, E. K.: Spatiotemporal variability of the precipitation dipole transition zone in the western United States, Geophys. Res. Lett., 37, L07706, https://doi.org/10.1029/2009GL042193, 2010.

Wise, E. K.: Five centuries of U.S. West Coast drought: Occurrence, spatial distribution, and associated atmospheric circulation patterns, Geophys. Res. Lett., 43, 4539-4546, https://doi.org/10.1002/2016GL068487, 2016.

Woodhouse, C. A. and Overpeck, J. T.: 2000 years of drought variability in the Central United States, B. Am. Meteorol. Soc., 79, 2693-2714, https://doi.org/10.1175/15200477(1998)079<2693:YODVIT>2.0.CO;2, 1998.

Worrall, J. J., Egeland, L., Eager, T., Mask, R. A., Johnson, E. W., Kemp, P. A., and Sheppard, W. D.: Rapid mortality of Populus tremuloides in southwestern Colorado, USA, Forest Ecol. Manag., 255, 686-696, https://doi.org/10.1016/j.foreco.2007.09.071, 2008.

Worrall, J. J., Marchetti, S. B., Egeland, L., Mask, R. A., Eager, T., and Howell, B.: Effects and etiology of sudden aspen decline in southwestern Colorado, USA, Forest Ecol. Manag., 260, 638648, https://doi.org/10.1016/j.foreco.2010.05.020, 2010.

Worrall, J. J., Rehfeldt, G. E., Hamann, A., Hogg, E. H., Marchetti, S. B., Michaelian, M., and Gray, L. K.: Recent declines of Populus tremuloides in North America linked to climate, Forest Ecol. Manag., 299, 35-51, https://doi.org/10.1016/j.foreco.2012.12.033, 2013.

Yarnal, B.: Synoptic climatology in environmental analysis: A primer, Belhaven Press, London, England, 1993.

Yarnal, B., Comrie, A. C., Frakes, B., and Brown, D. P.: Developments and prospects in synoptic climatology, Int. J. Climatol., 21, 1923-1950, https://doi.org/10.1002/joc.675, 2001. 